\title{
Natalia ROTAR
}

Narodowy Uniwersytet Czerniowiecki im. Jurija Fedkowycza

nata_rotar@ukr.net

\section{UCZESTNICTWO POLITYCZNE OBYWATELI UKRAINY: WYMIAR WYBORCZY, PROTESTACYJNY I DYSKURSYWNY}

ABSTRACT Political participation of Ukrainian citizens: electoral, protest, discursive measure

A complex research of the particularities of the Ukrainian citizens' participation in the cyclic political processes of transformational period has been provided. Logic of electoral cycles in Ukraine is being examined in the context of formation of the three dynamic models of citizens' participation - electoral, discursive and protest. It has been proved that citizens' usage of the protest model of political participation has multiple-factor determination, in which the fulfilment of the institutionalization of system opposition is the dominating element. It has been grounded that the most effective model of citizens' influence on political system is discursive model of political participation, which is able to guarantee system equilibrium in the structure of political system. The main features and mechanisms of formation of the dialogue form of Ukrainian citizens' political participation have been scrutinized. Perspectives of expansion of the range of political participation by means of the citizens using electronic devices of interaction with authorities, which are given to them by the resources of e-democracy, have been analyzed.

Key words: Ukraine, political participation, electoral model of political participation, discursive model of political participation, protest model of political participation, cyclic political process, electoral cycle.

Słowa kluczowe: uczestnictwo polityczne, obywatele Ukrainy, uczestnictwo wyborcze, uczestnictwo protestacyjne, uczestnictwo dyskursywne, wybory prezydenckie 
$\mathrm{K}^{\mathrm{o}}$ oniec lat 80 . i początek lat 90. XX w. dał Ukrainie historyczną szansę stworzenia niepodległego i demokratycznego państwa, zorientowanego na wartości ogólnoludzkie. Najważniejsza dla realizacji tych perspektyw była i pozostaje zasada ogólnonarodowej konsolidacji wokół idei państwowotwórczej, która w warunkach demokratycznego rozwoju zyskuje cechy różniące się całkowicie od sowieckiego etatyzmu. W latach niepodległości państwo ukraińskie przeszło skomplikowaną drogę odnowy politycznej, która pozwoliła zrozumieć, że demokracja to nie tylko całokształt instytucji i norm, nie tylko ukształtowana formalnie pod względem instytucjonalnym i prawnym struktura władzy. Jej nieodłącznym komponentem jest umotywowane uczestnictwo polityczne obywateli w organizacji i funkcjonowaniu władzy, które bazuje na uświadomionym pragnieniu występowania w roli pełnowartościowych, pełnoprawnych i kompetentnych podmiotów stosunków politycznych.

Kierunek zmian systemu politycznego Ukrainy nie został narzucony z zewnątrz, dlatego też zorientowany na Zachód scenariusz transformacji politycznych, zgodnie z którym obywatele przyswajają sobie zachodnioeuropejskie modele uczestnictwa politycznego ukształtowane $\mathrm{w}$ łonie społeczeństwa obywatelskiego, nie był w naszym kraju realizowany. Można mówić o realizacji na Ukrainie mieszanego scenariusza przekształceń postsocjalistycznych, łączącego w sobie cechy ewolucyjnego i zorientowanego na zewnątrz modelu rozwoju demokratycznego. W płaszczyźnie politycznej oznacza to nieodwracalność procesu transformacji w połączeniu z osłabieniem trendu transformacyjnego, i tak np. aktywne modele uczestnictwa politycznego, które zapewniały sukces procesów transformacyjnych na początku lat 90 . XX w., już w połowie tej dekady przestają być dominujące dla większości obywateli Ukrainy, zaczynających używać mniej efektywnych form uczestnictwa politycznego. To właśnie wtedy, po przyjęciu Konstytucji Ukrainy, dała się zaobserwować pewna bierność wobec intensyfikacji procesów transformacyjnych i bezwład w działaniach wszystkich segmentów elity politycznej.

Uczestnictwo polityczne obywateli Ukrainy podporządkowane jest cykliczności procesów wyborczych. Posługujemy się anglo-amerykańską tradycją studiowania cyklu wyborczego jako procesu od wyborów do wyborów (A. Alsena, M. Gartner, S. Kemani, S. Loman, M. Peldam), kiedy w okresie między wyborami metodą praktyki dyskursywnej określana jest logika kolejnej rywalizacji wyborczej, która na razie znajduje się na marginesie zainteresowań naukowych rodzimych naukowców. Zatem cykle wyborcze - będąc uporządkowaną sekwencją działań i współdziałań aktorów sceny politycznej, które odbywają się w logicznej dynamicznej kolejności i związane są $\mathrm{z}$ realizacją interesów władzy, stworzeniem i odtworzeniem politycznych instytucji, urzeczywistnieniem publicznej polityki - strukturalnie są tworzone przez syntezę trzech względnie samodzielnych i niezależnych etapów (etap przedwyborczy, etap wyborów, etap powyborczy), nierównoznacznych zarówno pod względem długości, jak i ich treści, jednakże gwarantują jednolitość cyklu wyborczego i jego odtworzenia w czasie politycznym. Logika cykli wyborczych i procesów demokratyzacji na 
Ukrainie sprzyjała kształtowaniu trzech głównych modeli uczestnictwa obywateli w procesach politycznych, w szczególności uczestnictwa wyborczego, dyskursywnego i protestacyjnego, których świadome użycie jest podstawą przekształcenia demokracji elektoralnej pod względem treści w realnie funkcjonującą w ciągu całego okresu od wyborów do wyborów.

\section{PARTYCYPACJA WYBORCZA OBYWATELI UKRAINY: PERSPEKTYWA PREZYDENCKICH CYKLI WYBORCZYCH}

Określenie specyfiki wyborczej partycypacji obywateli Ukrainy na przykładzie prezydenckich cykli wyborczych jest uwarunkowane tym, że po pierwsze, pierwszymi demokratycznymi wyborami na Ukrainie, które w politycznym czasie zbiegły się z ogłoszeniem niepodległości naszego państwa, były wybory prezydenta Ukrainy $1991 \mathrm{r}$. Właśnie one odegrały kluczową rolę w określeniu przez elitę polityczną zarówno treści samej demokracji, procesu demokratyzacji jako takiego, jak i parametrów politycznego dyskursu, miejsca i funkcji w nim obywateli. Po drugie, przeprowadzenie jako pierwszych wyborów prezydenta Ukrainy i odkładanie w czasie wyborów parlamentarnych doprowadziło do wyobrażenia o prezydenckich wyborach jako pierwszoplanowych, zaś o parlamentarnych jako drugorzędnych i z czasem utrwaliło je na poziomie instytucjonalnym, co dla wyborców nabrało charakteru rozdzielnego głosowania. Czyli innymi słowy, prezydenckie wybory rozumiane są przez obywateli Ukrainy jako ważniejsze, jako takie, które wyznaczają treść politycznego procesu w okresie między dowolnymi wyborami.

Mimo całego rozczarowania praktycznym funkcjonowaniem ukraińskiej demokracji wybory pozostają realnym mechanizmem zmiany władzy, a uczestnictwo obywateli w nich - instrumentem wpływu na proces polityczny. Właściwości modelu uczestnictwa wyborczego obywateli Ukrainy określone są przez wiele czynników o charakterze społeczno-ekonomicznym, ideologicznym, instytucjonalnym charakteru, które w całości kształtują mechanizmy/czynniki postrzegania rzeczywistości i samooceny, myślenia i działalności obywateli, co określa ich stosunek do instytucji sytemu politycznego i przywódców politycznych, a także odzwierciedla subiektywną gotowość do obierania tych czy innych życiowych punktów orientacyjnych, celów, wartości, norm i stereotypów uczestnictwa, formuł językowych, haseł itp. Wszystkie mechanizmy powiązane są między sobą systemem lejka przyczynowości, którego momentem wyjściowym jest poziom warunków społeczno-ekonomicznych rozwoju ukraińskiego społeczeństwa; może on być przeanalizowany na podstawie stosunku obywateli do przekształceń transformacyjnych w zakresie stosunków ekonomicznych.

Wyniki licznych badań socjologicznych świadczą o tym, że u większości obywateli Ukrainy w latach 90 . XX w. dominowała pasywna postawa życiowa, poleganie na państwowym paternalizmie, który stał się podstawą kształtowania zawyżonych ocze- 
kiwań w stosunku do struktur władzy ${ }^{1}$. Jednocześnie znaczna część obywateli Ukrainy operowała i operuje mieszanym typem rozpoznania stosunków rynkowych, a grupy zwolenników przede wszystkim rynkowego czy planowego systemu stosunków ekonomicznych są w przybliżeniu jednakowe. Stanowisko przeciwników radykalnych reform rynkowych w latach 90. determinowała nostalgia za sowiecką przeszłością, zapewnionym minimum materialnym i pewnością co do przyszłości. Ukształtowało się ono jako orientacja na bezpieczeństwo, stabilność, ochronę przed ryzykiem, związanym z przemianami w pierwszych latach XXI w. W ogóle obywatele Ukrainy oceniali rynkowe i planowe stosunki ekonomiczne nie tylko jako zjawiska społeczno-ekonomiczne, ale nadawali im także zabarwienie ideologiczne. Specyfikę tej oceny odzwierciedlają procesy identyfikacji partyjnej obywateli, których zakończenie zależy od instytucjonalnego designu systemu politycznego w postaci właściwości systemu wyborczego i podziału władz. W latach 90 . wybory parlamentarne postrzegane były przez ukraińskie społeczeństwo jako drugorzędne, a wszyscy prezydenci Ukrainy, którzy zwyciężali w wyborach, byli wysuwani jako kandydaci przy wykorzystaniu mechanizmów zebrań wyborców oraz zgłoszenia osobistego kandydata, z pominięciem zasobów partyjnych. Był to czynnik hamujący proces identyfikacji obywateli, którzy opierają się na przekonaniu, że partie nie wpływają na charakter władzy i jej kurs polityczny.

Charakter transformacji systemowych na Ukrainie i ocena przekształceń społeczno-ekonomicznych będących podstawą kształtowania decyzji wyborczych sprzyjały powstaniu trzech głównych grup wyborców: wyborca-wtaściciel - dokonujący świadomego wyboru politycznego na korzyść systemu politycznego, który gwarantuje przestrzeganie jego ekonomicznych praw i interesów; wyborca ideologiczny - który głosuje za pewnym modelem politycznym ustroju społecznego lub przeciw niemu, nie biorąc pod uwagę oceny własnego położenia ekonomicznego; nie-wyborca - obywatel, który nie posiada motywacji do obrony własnych interesów politycznych czy ekonomicznych, dlatego też nie bierze udziału w procesie głosowania lub głosuje w sposób nieumotywowany. Właśnie ta ostatnia grupa wyborców jest obiektem szczególnego zainteresowania władzy, ponieważ w okresie wyborczym jest ona zdolna reagować na instytucjonalną mobilizację aktywności politycznej.

W odróżnieniu od rywalizacyjnych, metody użycia autorytarnych zasobów administracyjnych (dalej: a-zasoby) wykorzystywane są przez władze do przekonania/zmuszenia wyborców, by głosowali na przedstawicieli władzy. W okresie kampanii wyborczej ten rodzaj a-zasobów staje się środkiem specyficznej mobilizacji wyborców w celu narzucenia im wyboru poprzez wpływ urzędników i kierowników różnych szczebli, co na ogół zniekształca całościowy charakter procesu swobodnego wyrażenia woli. Polem dla rozpowszechnienia praktyki użycia a-zasobów, która leży u podstaw form mobilizacyjnych politycznego uczestnictwa obywateli, jest tradycyjne odtworzenie między elitą i obywatelami w ukraińskim procesie politycznym relacji typu „protektor-klient”. Z re-

Н. Ротар, Політична участь громадян України у системних трансформащілх перехідного періоду,

Чернівці 2007, s. 110. 
guły inicjatywa przywrócenia mobilizacyjnych form uczestnictwa politycznego należy do przedstawicieli władz regionalnych lub lokalnych, które przy ich pomocy wykonują polecenia władzy centralnej w kwestii poparcia kursu politycznego i gwarantują własną legitymację. Faktycznie a-zasoby oznaczają skoncentrowanie przez lokalną elitę prawa do określenia wektora uczestnictwa wyborczego obywateli pod warunkiem milczącej zgody tych ostatnich. Naszym zdaniem z jednej strony związki „protektor-klient” są reakcją obronną społeczeństwa na perspektywę politycznej niestabilności, jednakże z drugiej stwarzają duże przeszkody na drodze demokratyzacji społeczeństwa ukraińskiego, kształtowania systemu relacji poziomych w sferze polityki i zastępują mechanizmy społeczeństwa obywatelskiego.

Z reguły obywatele Ukrainy wyrażają sprzeciw wobec twardych form a-zasobów. W przypadku gdy presję wywierają na nich przedstawiciele władzy, 57,3\% w każdych warunkach mimo wszystko głosuje tak, jak uważa za właściwe, 22,7\% - rezygnuje z udziału w wyborach, 15,1\% - udaje, że się podporządkowuje, jednak głosuje tak, jak uważa za właściwe, i tylko 3,5\% podporządkowuje się i głosuje tak, jak wskazują przedstawiciele władzy ${ }^{2}$. Skłania to władze do wykorzystywania w stosunku do wyborców miękkich form a-zasobów, przede wszystkim tych metod, które należą do sfery sytuacyjnego przedwyborczego poparcia socjalnego. Miękkie formy a-zasobów pozbawione są przymusu bezpośredniego i mogą przybierać następujące formy: przekazania odpowiedzialności - „głosuj na kogokolwiek, mamy do ciebie zaufanie”; stymulacji przyswojenia sobie przez wyborcę orientacji ukształtowanej za pomocą technologii komunikacyjnych - „o tym kandydacie tyle dobrego nam opowiadano”; otrzymanego przez wyborcę od członka komisji wyborczej zalecenia oddania głosu na konkretnego kandydata; ograniczenia rozpowszechniania informacji o pewnych kandydatach; przymusowego rozpowszechniania informacji przez kierowników władz państwowych, przedsiębiorstw, instytucji w celu publicznego poparcia tych czy innych kandydatów; nieprawidłowości podczas układania spisów wyborców - np. „rozdymanie” spisów obywateli, którzy mają prawo do głosowania w danym okręgu, kosztem tych ludzi, którzy nie mieszkają na jego obszarze, co otwiera większe możliwości manipulacji z kartami do głosowania; przeprowadzania podczas kampanii przedwyborczej akcji socjalnej czy pomocy dobroczynnej.

Jednym ze wskaźników efektywnego użycia przez władzę a-zasobów jako środków presji na obywateli jest rozpowszechnienie się wśród nich przekonania, że wyniki wyborów tak czy inaczej zostaną przeinaczone, sfabrykowane, sfałszowane. W 1994 r. taki pogląd reprezentowało tylko 12\% wyborców, w 1998 r. - 17\%, w 2001 r. $-23,3 \%^{3}$. Przeprowadzając analizę a-zasobów jako czynnika kształtowania modelu uczestnictwa wyborczego, należy wyodrębnić kategorie wyborców, którzy do ukończenia procesu kształtowania się demokracji na Ukrainie są najbardziej wrażliwi na działanie a-zasobów. Naszym zdaniem, najbardziej liczną i najbardziej wrażliwą

I. ЖАанов, Вибори-2002: соло для адміністративного ресурсу?, „Азеркало тижня” 2001, 22 XII, s. 4.

3 Tamże. 
grupą są mieszkańcy wsi, ponieważ problemy związane z ich powszednimi potrzebami społeczno-ekonomicznymi znajdują się pod całkowitą kontrolą organów samorządu lokalnego i miejscowej administracji państwowej, które w sytuacji wyborczej problemy te maksymalnie upolityczniają. Ta kategoria wyborców staje się podatną na a-zasoby również dlatego, że jest ona oddalona od kompleksu mediów i zmuszona do korzystania $z$ informacji rozpowszechnianych przeważnie przez telewizję oraz przedstawicieli władz lokalnych; cechuje ją znaczny stopień zubożenia i bezrobocia; wpływ na to ma również zależność kształtowania miejscowych budżetów organów samorządu lokalnego od sił politycznych popierających władzę; zależność inteligencji wiejskiej - której przedstawiciele przeważnie wchodzą w skład komisji wyborczych od administracji lokalnych; niedostateczny autorytet ośrodków partyjnych, uniemożliwiający konkurencję polityczną. Z reguły w stosunku do tej kategorii wyborców władza ucieka się do użycia twardych form wpływu administracyjnego, szczególnie w oddalonych od centrum wiejskich rejonach wschodnich i południowych obwodów Ukrainy. Do drugiej kategorii obywateli, którzy równocześnie są przedmiotem i podmiotem presji a-zasobów, należą urzędnicy państwowi i pracownicy budżetowych instytucji i organizacji, którzy nie mają statusu urzędników państwowych (pracownicy resortu oświaty, ministerstwa zdrowia czy kultury i sztuki). W kampanii wyborczej 1999 r. byli oni wykorzystywani przeważnie w celach agitacji. Tradycyjnym trzecim obiektem a-zasobów w latach 90. byli zależni od kierownictwa zakładów dydaktycznych ukraińscy studenci, którzy byli mobilizowani przez rektoraty do popierania kandydata władzy. Do czwartej kategorii, dość znaczącej pod względem liczebności i szczególnie wrażliwej na działania a-zasobów, należą rozproszone grupy obywateli - w jednostkach wojskowych, więzieniach, koloniach, szpitalach. Pierwsze próby użycia $a$-zasobów w stosunku do wojskowych władze przedsięwzięły już podczas kampanii wyborczej 1994 r., jednakże podczas wyborów 1999 r. nowe prawo wyborcze pozbawiło władzę możliwości wykorzystywania twardych form a-zasobów, ponieważ zostały zlikwidowane zamknięte okręgi wyborcze. Do szóstej kategorii wyborców, którzy są wrażliwi na a-zasoby, zaliczamy przedstawicieli grup etniczno-nacjonalnych, które w zwartych skupiskach zamieszkują pewne obszary. W danym wypadku nie jest wykorzystywana bezpośrednia czy nawet pośrednia presja, władza, z reguły, ucieka się do miękkich form a-zasobów należących do sfery poprawy szans społeczno-ekonomicznych i kulturalnych tej grupy - takich jak budowa ośrodków kulturalnych, poparcie zakładów oświatowych dla mniejszości narodowych - zrealizowanych w przeddzień wyborów oraz do ustanowienia bardziej bliskich i przyjacielskich stosunków z odpowiednim krajem, z którym zawierane są umowy dotyczące realizacji projektów inwestycyjnych. Faktycznie władza ucieka się do dość ryzykownych poczynań - mobilizacji wokół aspektów etnicznych, co może z czasem doprowadzić do ukształtowania się specyficznych, odmiennych od rozpowszechnionych na Ukrainie modeli partycypacji wyborczej4.

Н. Ротар, Етнонаціональні чинники політичної участі громадян України, „Наукові записки. Курасівські читання-2005. Політологія та етнологія” 2006, nr 30, ks. 1, s. 357-359. 
Mimo że wykorzystanie a-zasobów w stosunku do elektoratu staje się coraz mniej efektywne, ponieważ jego użycie znajduje się na granicy prawa lub stoi z nim w sprzeczności, przez co ma zdolność wywoływania efektu odwrotnego - spadku frekwencji wyborczej i wzrostu liczby głosujących przeciwko wszystkim kandydatom - istnieje trwała tendencja do ich stosowania. Czasami a-zasobom celowo przypisuje się publiczny charakter w okresie przedwyborczym, co prowadzi do świadomej rezygnacji wyborców z udziału w głosowaniu i stwarza podstawy do bardziej aktywnego użycia a-zasobów w fazie głosowania, ponieważ manipulować mniejszą liczbą wyborców (czy kart wyborczych) jest znacznie łatwiej.

Dość istotnym czynnikiem kształtowania treści wyborczego modelu uczestnictwa politycznego są przedwyborcze programy kandydatów, które aktualizują i koncentrują krąg problemów rozwoju politycznego kraju w perspektywie krótkoterminowej, prognozują polityczny kurs w polityce wewnętrznej i zewnętrznej. Mimo że pod wieloma względami są one podobne i względnie różnią się co najwyżej biografiami kandydatów i niuansami poglądów politycznych, znanych przed rozpoczęciem wyborów, właśnie hasła przedwyborcze kandydatów na prezydenta i partii politycznych podczas wyborów parlamentarnych pozwalają wyborcom rozłożyć pewne akcenty i uzmysłowić sobie prawdopodobny model rozwoju politycznego, realizowany przez polityka w razie zwycięstwa. Programy przedwyborcze wszystkich kandydatów na prezydenta Ukrainy w latach 1991-2014 były budowane na zasadach modelu konwergencji, kiedy stanowiska kandydatów rozkładają się wokół środka preferencji wyborców centrowych. Jednak na etapie przedwyborczym kandydaci transformowali założenia programowe zgodnie z modelem indyferentności, podczas gdy główni rywale aktualizują różne aspekty programu, w tym również jego komponent zewnętrzno-polityczny, co prowadzi do dyskusji społecznej o różnych pod względem treści problemach i do braku możliwości porównania przez wyborców stanowiska kandydatów wobec tego samego zagadnienia. Przyczyna tego leży przede wszystkim w tym, że jądro wyborcze głównych rywali w wyborach prezydenckich na Ukrainie tworzone jest z przedstawicieli wszystkich bez wyjątku grup społeczno-demograficznych.

Po przeanalizowaniu głównych czynników kształtowania decyzji wyborczych obywateli Ukrainy wyjaśnimy, w jaki sposób przejawiły się one w realnym czasie kampanii wyborczych. Jedną z najważniejszych cech uczestnictwa wyborczego obywateli jest poziom ich aktywności w chwili głosowania. Najwyższe wskaźniki aktywności wyborczej odnotowano podczas wyborów prezydenckich 1991 r. Wówczas w wyborach pierwszego prezydenta Ukrainy wzięło udział 84,32\% wyborców, co tłumaczy się, po pierwsze, działaniem czynnika automatycznego odtworzenia sowieckich tradycji uczestnictwa wyborczego, które rozumiane było przez ludność i propagowane przez władzę jako obowiązkowe, po drugie, doniosłością wyborów, które odbywały się równocześnie z referendum na temat niepodległości Ukrainy. Maksymalnie zbliżony poziom aktywności obywateli podczas głosowania w wyborach prezydenta Ukrainy został odnotowany podczas dramatycznych wyborów 2004 r., w trakcie ponownego głosowania 21 listopada. 
Dodajmy, że w wyborach prezydenckich 2014 r. - mimo iż wybory te były faktycznie wyborem cywilizacyjnym Ukrainy - frekwencja wyborcza wyniosła zaledwie $59,87 \%{ }^{5}$. Do pewnego stopnia tłumaczy się to tym, że udziału w głosowaniu nie mogli wziąć wyborcy anektowanego Krymu i tych obszarów Ukrainy, na których miały miejsce lokalne konflikty zbrojne, przede wszystkim obwodu ługańskiego i donieckiego. Według wyników badania, przeprowadzonego przez fundację Inicjatywy Demokratyczne, tylko 12,7\% potencjalnych wyborców z obwodów ługańskiego i donieckiego udzieliło odpowiedzi, że ich zdaniem w ich okręgach wyborczych odbywają się wybory. Ponad połowa $(55,1 \%)$ powiedziała, że wybory nie są przeprowadzane, a jedna trzecia $(32,2 \%)$ nie wiedziała, czy odbywają się wybory. Na pytanie o zamiar głosowania $17,3 \%$ respondentów stwierdziło, że próbowali, lecz nie zdołali zagłosować, a $67 \%$ - że nie zamierzają iść do okręgów wyborczych. Z tych, którzy nie zamierzali głosować, 30,5\% wiedziało, że to niemożliwe (spośród nich $20,7 \%$ wiedziało, że ich komisja jest nieczynna, 9,8\% - że w ich miejscowości wybory w ogóle nie są przeprowadzane), 26,2\% powiedziało, że nie widzą godnego kandydata, 6,8\% - że pójście na wybory jest niebezpieczne, $12,4 \%$ - że nie wierzy w uczciwość wyborów, 7,7\% - że ich region nie jest już częścią Ukrainy, pozostali nie mogli z powodów rodzinnych oraz innych przyczyn ${ }^{6}$.

Tak więc dla obywateli Ukrainy udział w głosowaniu jest sprawą istotną, nawet mimo że czasami sam fakt uczestnictwa jest ważniejszy niż poparcie jakiegoś kandydata. Taka specyfika uczestnictwa wyborczego ukraińskich obywateli potwierdza znaczenie analizy jej geostruktury, która pod względem złożoności koreluje nie tylko ze strukturą systemu partyjnego, lecz również ze strukturą orientacji polityczno-ideologicznych obywateli naszego państwa, bazuje na wyznaczeniu głównych modeli terytorialnych głosowania i ukształtowanym modelu stosunków centrowo-peryferyjnych. S. Lipset i S. Rokkan uważają centrowo-peryferyjną oś podziału społeczeństwa za ukryte źródło konfliktów politycznych ${ }^{7}$. Na Ukrainie napięcie centrowo-peryferyjne jest podsycane przez fakt, że praktyka wyborcza regionów Ukrainy ma różny wymiar czasowy i znaczeniowy, co spowodowane jest przez doświadczenie rozwoju historycznego, co z kolei aktualizuje problem integralności politycznej naszego państwa.

Problem politycznej integralności Ukrainy nabrał aktualności już na początkowym etapie tworzenia państwa. Między innymi w 1991 r. lider socjalistów O. Moroz, wyrażając stanowisko swojej partii (SPU), oświadczył: najważniejszym wśród dzisiejszych problemów naszego spoteczeństwa jest problem jego jedności. Wtaśnie dlatego Ukrainie potrzebny jest prezydent, zdolny do bycia gwarantem jedności. Potrzebny jest prezydent

Позачергові вибори Президента України 25 травня 2014 року. Примірник Nr 1. Протокол Центральної Виборчої Комісії „Про результати Виборів Президента України”, Центральна виборча комісія, [online] http://www.cvk.gov.ua/info/protokol_cvk_25052014.pdf.

6 Проблеми проведення президентських виборів у Аонещькій і Ауганській областях, ФонА „Аемократичні ініціативи імені Іцька Кучеріва”, 25 V 2014, [online] http://dif.org.ua/ua/polls/2014_polls/ sdmnvkasjovjojvoajf.htm.

С. Аипсет, Структуры размежеваний, партийнье системь и предпочтения избирателей, [w:] С. Аипсет, С. Роккан, Партии и выьборь. Хрестоматия, red. Н. Анохина, Е. Мемешкина, сz. 1, Москва 2004, s. 70. 
jako uosobienie zaufania narodu ${ }^{8}$. Teza ta ma swoje podstawy, ponieważ już podczas pierwszych wyborów prezydenta Ukrainy wyraźnie zarysowała się geostruktura wyborczych preferencji wyborców - polityczna mniejszość skupiła się w trzech zachodnich obwodach kraju - lwowskim, tarnopolskim i iwanofrankowskim, w których na najbardziej popularnego kandydata sił narodowo-demokratycznych W. Czornowoła oddało głos odpowiednio 75,9\%, 57,4\% i 67,1\% wyborców, podczas gdy ogólnie zwycięstwo na Ukrainie odniósł L. Krawczuk9 . Główną tendencją tych wyborów stał się wyraźny spadek poparcia dla patriotycznych i zorientowanych demokratycznie sił politycznych zgodnie z osią zachód-centrum-południe-wschód, która z każdym cyklem wyborów prezydenckich stawała się bardziej widoczna na poziomie modelowania uczestnictwa wyborczego wyborców z tych regionów.

Poczynając od wyborów 1994 r., można mówić o pewnej stabilności wyborczej geostruktury Ukrainy, która szczególnie wyraźnie utrwaliła się w drugich turach wyborów prezydenckich 1994 r. i 1999 r. oraz we wszystkich trzech turach wyborów w 2004 r. Wyniki głosowania podczas wyborów prezydenckich 1994 r. pokazały istotną różnicę w preferencjach wyborczych regionów Ukrainy, która odzwierciedliła kontrowersje w systemie politycznych i ideologicznych orientacji wyborców. Dwukrotnie L. Krawczuk zwyciężał w zachodnich i centralnych obwodach Ukrainy, a L. Kuczma we wschodnich i południowych obwodach oraz na Krymie. Należy podkreślić, że we wszystkich regionach, gdzie w 1994 r. wyborcy oddali głosy na L. Kuczmę, w 1999 r. zwycięstwo zdobył P. Symonenko. W sposób przekonujący dowodzi to, po pierwsze, dychotomicznego rozkładu głosów według systemu wartości ideologicznych, a po drugie, stabilności orientacji ideologicznych obywateli Ukrainy, ponieważ w drugim cyklu wyborczym L. Kuczma wykorzystywał image czerwonego dyrektora, popularnego na wschodzie Ukrainy, podczas gdy w trzecim cyklu wyborczym występował on z pozycji propaństwowych i antykomunistycznych, powszechnych wśród obywateli zachodnich obwodów Ukrainy. W dodatku partycypacja wyborcza w drugiej turze wyborów prezydenckich 1999 r. w przypadku większości obywateli zachodnich regionów państwa była rodzajem protestu, ponieważ głosowali oni nie na L. Kuczmę, a przeciwko jego konkurentowi P. Symonence, który uosabiał groźbę powrotu do komunistycznej przeszłości.

Geostruktura głosowania w drugiej turze wyborów 1999 r. ujawniła szereg zasadniczych cech modelu wyborczego uczestnictwa politycznego obywateli w etapach wyborczych prezydenckich cykli elektoralnych. Po pierwsze, wyraźnie zarysowała się tendencja do obniżenia aktywności wyborczej obywateli. W wyborach wzięło udział tylko $68,4 \%$ wyborców, przy czym na wschodzie i południu Ukrainy te wskaźniki były jeszcze niższe - w obwodzie donieckim udział w głosowaniu wzięło $62,5 \%$ obywateli z prawem głosu, na Krymie - 60,4\%. Po drugie, swoją ideologiczną jedność zademonstrowali obywatele zachodnich obwodów Ukrainy - lwowskiego, iwanofrankowskiego

Про Президентство, [w:] Матеріали I-V з’̈здів Соціалістичної партії України, red. О. Мороз, t. 1: 1991-1994, Київ 1997, s. 17.

9 Офіиійні результати виборів Президента Украйни 1 грудня 1991 р., „Урядовий кур’єр” 1991, nr 38-39, s. 1. 
i tarnopolskiego, na której tle ewidentna staje się odmienność polityczno-ideologicznej identyfikacji obywateli obwodów czerniowieckiego i zakarpackiego. Po trzecie, analiza geostruktury protestacyjnego głosowania obywateli podczas wyborów 1999 r. przekonuje, że udział głosów oddanych przeciwko wszystkim kandydatom jest wyższy na wschodzie i południu Ukrainy i stopniowo zmniejsza się ze wschodu na zachód. Wyjątek stanowi głosowanie wyborców w obwodach ługańskim i sumskim, w których potencjał protestu realizowany był przez obywateli poprzez głosowanie odpowiednio na P. Symonenkę i N. Witrenko. Po czwarte, osobliwością geostruktury uczestnictwa wyborczego w wyborach 1999 r. jest też to, że wyborcy, którzy poparli kandydatów bez szans na przekroczenie progu wyborczego w pierwszej turze (od 1 do $15 \%$ głosów poparcia), skupieni są przeważnie w centralnych i wschodnich regionach Ukrainy ${ }^{10}$. Po piąte, regiony Ukrainy, w których odnotowuje się najwyższe poparcie dla lidera partii komunistycznej P. Symonenki - z reguły wysoko zurbanizowane - charakteryzują się niskim poziomem aktywności obywateli w kampaniach wyborczych i wysokim poziomem protestacyjnego głosowania zarówno podczas prezydenckich, jak i parlamentarnych wyborów.

Tak więc, wyniki wyborów prezydenckich w 1991, 1994 i 1999 określały wschodnie regiony Ukrainy, chociaż ich zwycięzcy zawsze wykorzystywali ideologię zachodnich regionów kraju. Faktycznie zachodnia Ukraina od początku przekształceń postsocjalistycznych była ośrodkiem innowacji politycznych z dosyć pragmatyczną orientacją na kijowskich polityków typu prozachodniego, demokratycznego, podczas gdy wschód państwa był pod tym względem peryferium. Dość efektywnie wykorzystywany był schemat, zgodnie z którym wschód kontrolował ekonomię kraju, a zachód formułował państwową ideologię, określał system edukacji i politykę zewnętrzną. W wyborach $2004 \mathrm{r}$. po raz pierwszy ogólnonarodowe przywództwo zdobył W. Juszczenko, polityk, którego idee były adekwatne do politycznego centrum Ukrainy - obwodów zachodnich.

Zwycięzca wyborów prezydenckich 2014 r. P. Poroszenko, który zdobył zwycięstwo w pierwszej turze z poparciem 54,70\% wyborców, również nie cieszy się równomiernie rozłożonym po regionach Ukrainy poparciem wyborczym. W szesnastu regionach Ukrainy na P. Poroszenkę zagłosowało ponad 50\% wyborców (obwód winnicki 67,32\%, wołyński - 52,41\%, żytomierski - 58,64; zakarpacki - 62,02\%, iwanofrankowski - 65,13\%, kirowogradzki - 50,96\%, kijowski - 61,67\%, lwowski - 69,92\%, połtawski $-54,55 \%$, rówieński $-55,46 \%$, sumski $-55,40 \%$, tarnopolski - 60,63\%, chmielnicki - 56,26\%, czerkaski - 64,61\%, czerniowiecki - 56,72\%, m. Kijów 64,10\%), a w dziewięciu regionach głosowała na niego mniej niż połowa wyborców (obwód dniepropetrowski - 44,72\%, doniecki - 36,15\%, zaporoski - 38,15\%, lugański - 33,17\%, mikołajewski - 45,97\%, odeski - 41,78\%, charkowski - 35,28\%, chersoński - $48,71 \%$, czernihowski $-44,81 \%)^{11}$. Przytoczona statystyka wyborcza potwier-

10 Вибір України-99. Що далі. Збірник статей і довідкових матеріалів, red. Я. Хобота і іп., Київ 1999, s. $105,107$.

11 Позачергові вибори Президента України 25 травня 2014 року. Підсумки голосування в межах регіонів України, [online] http://www.cvk.gov.ua/vp2014/wp001.html. 
dza, że odnotowana geostruktura uczestnictwa wyborczego w wyborach prezydenckich w latach 1991-2004 została odtworzona również podczas wyborów prezydenckich 2014 r., jednak tradycyjnie neutralne centralne i północne obwody Ukrainy poparły proeuropejskiego kandydata już w pierwszej turze głosowania. Co do głównego konkurenta P. Poroszenki, J. Tymoszenko, to poparcie dla niej w wymiarze regionalnym waha się od maksymalnego w obwodzie czernihowskim (19,48\%) do minimalnego w charkowskim (7,64\%), przy przeciętnym wskaźniku na Ukrainie $12,82 \%^{12}$.

Zwycięstwo P. Poroszenki jest uwarunkowane przede wszystkim jego zachowaniem i rolą podczas protestów i akcji Euromajdanu, osobistymi zaletami jako człowieka oraz zawartym z W. Kliczką porozumieniem o podziale władzy.

$\mathrm{Na}$ tle wyniku zwycięzcy stosunkowo słaby wynik osiągnięty w wyborach przez J. Tymoszenko (12,81\%) można wytłumaczyć zarówno jej długotrwałym przebywaniem w izolacji, jak i utratą umiejętności odczuwania kraju, a także zapotrzebowaniem wyborców na „nowe twarze” w polityce. Sukces w wyborach O. Laszki (8,32\% głosów „za”) można ocenić w ramach społecznej potrzeby istnienia głosów radykalnych i prostych decyzji, które zostały zaproponowane przez kandydata $\mathrm{w}$ formie radykalnego skandalizującego populizmu ${ }^{13}$.

Specyfika modelu wyborczego uczestnictwa politycznego obywateli Ukrainy w wielu aspektach była określana przez istniejącą do ostatnich wyborów prezydenckich 2014 r. możliwość uciekania się do wyborczych form protestu politycznego. Protestacyjne uczestnictwo wyborcze obywateli naszego kraju nie ukształtowało się na poziomie pewnego modelu, jednakże jego analiza uświadamia zdolność przekształcania się protestu wyborczego $\mathrm{z}$ form utajonych (świadoma odmowa głosowania podczas ogólnonarodowych i miejscowych wyborów; głosowanie przeciwko wszystkim; głosowanie na ewidentnych outsiderów maratonu wyborczego) w aktywne. Z zarysowanych utajonych form protestu wyborczego dość znaczący potencjał informacyjny ma głosowanie przeciw wszystkim (nie popieram żadnego kandydata).

Obywatele, operując instrumentalną motywacją wyboru, nie są skłonni do wykorzystywania protestacyjnych form głosowania w wyborach do ważniejszych instytucji politycznych, ponieważ to one określają przyszły kurs polityki. Podczas wyborów drugorzędnych tradycyjnie jest widoczna fala głosowania protestacyjnego, którego celem jest ukaranie władzy za niezadowalający kierunek polityki, demonstrowanie braku zaufania do sił politycznych biorących udział w wyborach itp. Wzrost liczby obywateli, którzy nie popierają żadnego z kandydatów na prezydenta, tłumaczy się tym, że wyborcy nie zgadzają się z istniejącymi regułami gry politycznej, faktycznym brakiem alternatywy w wyborach lub koniecznością wyboru między dwoma kandydatami nieodpowiadającymi nastrojom wyborców. Wszystkie zarysowane powyżej aspekty uciekania się obywateli do protestacyjnych form głosowania potwierdza praktyka procesu politycznego na Ukrainie w latach 1991-2004 (tab. 1).

12 Позачергові вибори Президента України 25 травня 2014 року. Підтримка лідерів по регіонах, [online] http://www.cvk.gov.ua/vp2014/wp001.html.

13 Позачергові вибори Президента України 25 травня 2014 року. Примірник Nr 1. Протокол..., s. 51. 
Tabela 1. Głosowanie protestacyjne w wyborach prezydenckich na Ukrainie (dane w \%)

\begin{tabular}{|c|c|c|c|c|c|c|c|c|c|}
\hline & \multicolumn{2}{|c|}{1994 r. } & \multicolumn{2}{|c|}{1999 r. } & \multicolumn{3}{c|}{2004 r. } & \multicolumn{2}{c|}{2010 r. } \\
\hline $\begin{array}{c}\text { Nie popieram } \\
\text { zadnego kandydata }\end{array}$ & I tura & II tura & I tura & II tura & I tura & II tura & II tura & I tura & II tura \\
\cline { 2 - 11 } & 3,43 & 2,80 & 1,81 & 3,44 & 1,98 & 2,31 & 2,34 & 2,20 & 4,36 \\
\hline
\end{tabular}

Źródło: Вибори Президента Украӥни 1999. Інформаційно-аналітичне видання, red. М. Рябець, М. Ставнійчук, Київ 2000, s. 285-287; Вибори Президента України 2004 року. Електоральна статистика. Інформачійно-аналітичне видання, red. Я. Аавидович, Київ 2005, s. 478, 491, 492; Вибори Президента України. Повторне голосування 7 лютого 2010 року. Протокол Центральної виборчої комісії про результати повторного голосування з виборів Президента України, s. 2, Центральна виборча комісія, [online] http://www.cvk.gov.ua/visnyk/pdf/2010_1/visnik_st_4.pdf.

Analiza danych tabeli 1, przeprowadzona według metodyki przewidującej następujące dane szacunkowe poziomu głosowania protestacyjnego: ponad $6 \%$ - poziom wysoki; 4,8-5,99\% - średnio-wysoki; 3-4,79\% - średnio-niski; poniżej 3\% - niski ${ }^{14}$, potwierdza, że na Ukrainie znajdowało się ono w strefie wskaźników niskich i średnio-niskich, a najniższy wynik odnotowano podczas wyborów 2010 r. Wyniki badań socjologicznych pokazują, że wskaźniki liczbowe protestacyjnego głosowania pokrywają się z liczbą tych obywateli, dla których głównym motywem uczestnictwa w wyborach jest głosowanie przeciwko konkretnemu kandydatowi $(2,1 \%)^{15}$. Skłonność obywateli do wykorzystania głosowania-protestu ulega istotnemu osłabieniu wraz ze zbliżaniem się wyborów. Na przykład, o ile w marcu 1999 r. gotowość głosowania przeciwko obydwu kandydatom w drugiej turze, jeśli do niej wejdą P. Symonenko i L. Kuczma, zadeklarowało $25 \%$ respondentów, którzy byli pewni, że wezmą udział w głosowaniu, to w czerwcu 1999 r. ich udział zmniejszył się do 19\%, w sierpniu i wrześniu wynosił po $18 \%$, w październiku - 15\%, listopadzie - 3\%, co koreluje z oficjalnymi wynikami drugiej tury wyborów prezydenckich 1999 r. ${ }^{16}$

Model głosowania protestacyjnego zakłada zatem dopuszczalność wyrażenia woli w kwestii zamiarów wyborczych mających na celu odmowę poparcia dla wszystkich zgłoszonych kandydatów poprzez skreślenie na karcie wyborczej wszystkich nazwisk kandydatów lub wybranie wariantu - nie popieram żadnego kandydata. Głosowanie protestacyjne, którego podstawą jest brak zaufania do organów władzy albo do samej władzy, jest świadomym wyborem obywatela. Na użycie protestacyjnych form wyborczych uczestnictwa politycznego wpływają czynniki instytucjonalne, zasoby (płeć, wiek, edukacja, dochód) oraz środowisko. Na Ukrainie głównymi czynnikami

14 А. Ахременко, Е. Мелешкина, Голосование „Против всех” как форма политического протеста: проблемы изучения, „Политическая наука” 2002, nr 1, s. 45-46.

15 Програма Freedom House „Участь громадян у вибориих прочесах в Україні”. Ставлення громадян України до інституту виборів та їх наміри участі у виборах, [online] http://www.freedomhouse. org.ua/print/publications/investigations/.

16 О. Балакірєва, М. Міщенко, О. Яременко, Аинаміка та чинники формування електоральних орієнтачій громадян України під час виборчої кампаніїі, „Помітичний портрет України” 2000, nr 22, s. 146. 
określającymi wybór protestacyjnego wariantu głosowania było subiektywne poczucie niezadowolenia z rzeczywistości, rozbieżność między oczekiwaniami i realnymi możliwościami obywateli, różnica między normatywną i deskryptywną oceną systemu politycznego, niezadowolenie z działalności poszczególnych instytucji politycznych, brak zaufania do nich. Na Ukrainie, gdzie demokratyczne standardy wyborów i procesu wyborczego dosyć często są naruszane, istnienie protestacyjnego wariantu głosowania było dla obywatela szansą wyrażenia niezadowolenia z tego, jak przebiega proces wyborów, a dla polityków nabierało znaczenia pomocniczego w wyjaśnianiu nastrojów społecznych wyborców.

$Z$ reguły poziom aktywności protestacyjnej obywateli wzrasta wówczas, gdy poszczególne instytucje polityczne nie są zdolne do efektywnego wykonywania swoich podstawowych funkcji, gdy uczestnictwo polityczne obywateli określane jest przeważnie przez mobilizacyjne praktyki władzy, które podtrzymują i transmitują w systemie stosunków politycznych bezkształtny pluralizm, naznaczony wysokim stopniem fragmentacji podmiotów procesów wyborczych, kiedy żaden z nich nie jest zdolny do zajęcia dominującej pozycji lub skierowania swoich działań na osiągnięcie konsensusu politycznego. Taka sytuacja może prowokować obywateli do użycia bardziej aktywnych form protestacyjnego uczestnictwa wyborczego poza komisjami wyborczymi.

Takim przejawem przekształcenia niezadowolenia ze sposobu funkcjonowania systemu politycznego w protest wyborczy obywateli jest zjawisko, które otrzymało nazwę pomarańczowej rewolucji. Określenie jej istoty, która terminologicznie mogłaby zostać skonkretyzowana w kategoriach nauki politycznej, również dziś należy do sfery dyskursywnej nauk społecznych. Pomarańczowa rewolucja nie była rewolucją według którejkolwiek z cech klasycznych, był to sterowany ruch transformacyjny, zorientowany na modernizację polityczną i ekonomiczną; ruch ten był ideologicznie i psychologicznie nacechowany i miał duże szanse na zwycięstwo. Jednakże metafora pomarańczowa rewolucja jest najbardziej udaną metaforą, która określała potrzebę szybkich gruntownych zmian zasad funkcjonowania systemu politycznego i była zdolna do zmobilizowania obywateli Ukrainy do wykorzystania konwencjonalnych form uczestnictwa protestacyjnego. Dlatego też, naszym zdaniem, dość adekwatnym odzwierciedleniem istoty przebiegu wyborów prezydenckich 2004 r., szczególnie w fazie głosowania, jest kategoria aktywnego protestu wyborczego obywateli. W danym kontekście jednym z głównych zagadnień, które wymaga naukowego rozwiązania, jest wyjaśnienie przyczyn kształtowania politycznego niezadowolenia obywateli Ukrainy w formie aktywnego protestu wyborczego właśnie podczas wyborów prezydenckich 2004 r., a nie np. podczas wyborów prezydenckich 2002 r. Przecież w tym czasie przywództwo polityczne W. Juszczenki uzyskało znaczące poparcie obywateli, a oceny reżimu L. Kuczmy były najniższe w ciągu całego okresu sprawowania przez niego władzy. Pośrednim dowodem niskiego rankingu „demokracji” Kuczmy, swoistą deklaracją kształtowania przesłanek dla przekształcenia potencjalnego protestacyjnego uczestnictwa wyborczego w realne stała się samoocena obywateli w kwestii szans samorealizacji politycznej: w latach 1994-2000 od 50,7 do 60\% z nich oświadczało, że mogli swobodnie 
deklarować swoje stanowisko polityczno-ideologiczne, podczas gdy od 2001 r., kiedy taki pogląd reprezentowało $35,1 \%$ obywateli, wskaźniki te stale spadały ${ }^{17}$.

W przeddzień wyborów $84,4 \%$ obywateli uważało, że mają prawo wyjść na ulice z akcją protestu w przypadku sfałszowania wyników wyborów, jednak we wrześniu 2004 r. tylko 17\% uznało za możliwe użycie aktywnych działań na rzecz zrewidowania wyników wyborów, łącznie z masowymi akcjami obywatelskiego nieposłuszeństwa, i było gotowych osobiście wziąć w nich udział (w listopadzie ich liczba wzrosła do $19,4 \%)$. Istotnie wzrósł również poziom werbalnej gotowości protestacyjnej obywateli Ukrainy $-84 \%$ wyraziło przekonanie, że w przypadku naruszenia prawa do swobodnego wyrażenia woli obywatele Ukrainy mają prawo do akcji obywatelskiego nieposłuszeństwa, a 17-19\% wyraziło gotowość do osobistego wzięcia w nich udziału ${ }^{18}$.

Naszym zdaniem można wyróżnić przynajmniej trzy przyczyny efektywnej masowej mobilizacji politycznej obywateli Ukrainy na rzecz poparcia idei pomarańczowej rewolucji. Pierwsza ma charakter instytucjonalny i jest określana przez właściwości designe’u systemu politycznego Ukrainy. Szczególnie w sytuacji, gdy prezydent państwa jest obdarzony większymi uprawnieniami aniżeli jakakolwiek inna instytucja systemu politycznego, wyborcze cykle prezydenckie przekształcają się dla obywateli w pierwszoplanowe, a wybory parlamentarne stają się drugorzędnymi. Podobnie jak w innych krajach, wybory prezydenckie dla ukraińskiego wyborcy są potencjalnie bardziej sprzyjającym tłem dla wyrażenia protestu - od głosowania-protestu do aktywności protestacyjnej. Rozumiejąc, że instytucja prezydentury jest bardziej wpływowa od innych w systemie stosunków politycznych, obywatele starają się przez partycypację wyborczą wpłynąć właśnie na nią. W tym kontekście trzeba rozumieć również przesłankę organizacyjno-polityczną pomarańczowej rewolucji. Zwycięstwo B. Juszczenki w wyborach prezydenckich 2004 r. było faktycznie przygotowane przez rozwój procesu politycznego na Ukrainie w latach 2000-2004. Szczególnego znaczenia dla kształtowania ideologicznych, psychologicznych i politycznych podstaw pomarańczowej rewolucji nabiera utworzenie i działalność siły politycznej o nazwie Nasza Ukraina, która przemówiła pełnym głosem podczas wyborów parlamentarnych 2002 r. Jeżeli wziąć pod uwagę niejednakowe znaczenie wyborów prezydenckich i parlamentarnych na Ukrainie, głównym jej zadaniem, które zostało z powodzeniem wykonane, stało się utrzymanie poparcia obywateli do $2004 \mathrm{r}$.

Druga przyczyna udanej mobilizacji politycznej obywateli - technokratyczna związana jest $\mathrm{z}$ brakiem skutecznego mechanizmu reprezentacji całego spektrum interesów społecznych ludności naszego państwa, wskutek czego naruszona została równowaga interesów między elitą i obywatelami, co szczególnie dało się odczuć w przeddzień wyborów prezydenckich 2004 r. Dało to możliwość ekipie W. Juszczenki pomyślnego wykorzystania jednego z wariantów rozkręcania spirali uczestnic-

17 Політичні партіӥ в Україні напередодні парламентських виборів: стан і тенденцї (Аналітична доповідь УЦЕПА), „Націонамьна безпека і оборона” 2001, nr 12, s. 16.

18 Україна, 2004 рік: перебіг президентської виборчої кампанії очима громадян, „Національна безпека і оборона" 2004, nr 10, s. 2-20. 
twa politycznego, opisanego w schemacie populistycznego modelu funkcjonowania systemu politycznego przez P. Sharana ${ }^{19}$. Zgodnie z nim nadmierna nierówność majątkowa, która negatywnie odbija się na rozwoju społeczno-ekonomicznym, zawsze doprowadza do destabilizacji reżimu politycznego; opozycja zyskuje więc realną możliwość rozszerzenia ram uczestnictwa politycznego obywateli w procesie politycznym. $\mathrm{Na}$ Ukrainie sprzyjało temu wykorzystanie nowego schematu konfliktu w kampanii prezydenckiej: pomiędzy etatyzmem W. Janukowycza i podejściem propaństwowym W. Juszczenki. Poprzez aktualizację problemu wyboru optymalnej strategii między kierunkami rozwoju narodowego i demokratycznego ekipa W. Juszczenki spróbowała przekształcić ideę tożsamości narodowej w ideę tożsamości europejskiej, która zdolna jest do zjednoczenia Ukrainy i legitymizacji procesu zmiany władzy. W dodatku logika bipolarnego współzawodnictwa w wyborach 2004 r. doprowadziła do konsolidacji wokół W. Juszczenki różnych części elity politycznej Ukrainy, których wspólną cechą stała się zdolność mobilizowania obywateli do wykorzystania form protestacyjnych uczestnictwa wyborczego.

Przedstawiciele opozycji oceniali, że w razie masowego fałszowania wyników głosowania, że zmobilizują 200-300 tys. swoich aktywnych zwolenników, skoncentrowanych głównie w stolicy Ukrainy. Po drugiej turze wyborów udział obywateli, którzy zamierzali przeciwstawić się fałszowaniu wyników wyborów, wzrósł do $31 \%$, własny udział w akcjach nieposłuszeństwa potwierdziło prawie $22 \%$ obywateli Ukrainy. Realnie z protestami przeciwko fałszerstwom na wielką skalę, na wiecach poparcia dla W. Juszczenki w Kijowie i innych ośrodkach regionalnych Ukrainy zbierało się od 50 do 150 tys. obywateli, a w ciągu tygodnia po drugiej turze wyborów liczba protestujących w Kijowie osiągnęła milion obywateli. Jego głównego rywala - W. Janukowycza - na podobnych zgromadzeniach popierało od tysiąca do 30 tys. obywateli.

Trzecia przyczyna masowego poparcia przez obywateli pomarańczowej rewolucji ma charakter subiektywny: poczuli się oni oszukani. Kampania wyborcza 2004 r. nabrała cech wyboru moralno-eschatologicznego między dobrem i złem, prawdą i krzywdą, sprawiedliwością i niesprawiedliwością, spowodowanego użyciem agresywnych konfliktowych technologii politycznych oraz retoryką polityczną kandydatów. Według obliczeń KWU [Komitet Wyborców Ukrainy - ogólnoukraińska organizacja społeczna - przyp. tłum.] sfałszowanych zostało około 2,8 mln głosów, zwłaszcza w obwodach donieckim, ługańskim, zaporoskim i mikołajowskim ${ }^{20}$. Oceniwszy skalę fałszerstw, uświadomiwszy sobie, że bez ich odpowiednich wysiłków nie ukształtują i nie zakorzenią się instytucje demokratyczne władzy publicznej, nie powstanie porządek prawny, nie uzyska się możliwości realizacji w pełnym zakresie i ochrony własnych praw politycznych i swobód, obywatele wspólnym wysiłkiem wy-

19 П. Шаран, Сравнительная политология, сz. 2, Москва 1992, s. 181.

Т. Байхельт, Р. Павленко, Президентські вибори і конституційна реформа, [w:] Президентські вибори та Помаранчева револючія. Вилив на трансформаційні прочеси в Україні, red. Г. Курт, I. Кемпе, В. АнАрійко, Київ 2005, s. 65. 
stąpili na Majdanie. Wyborcze uczestnictwo polityczne obywateli Ukrainy w tym przypadku miało cechy bardziej autonomiczne, niezależnie od tego, z jakiego punktu widzenia je analizujemy.

Analizując charakter i przyczyny pomarańczowej rewolucji, obywatele Ukrainy bardziej skłonni są uważać ją za zorganizowaną akcję sił politycznych, pośrednio przyznając, że ich udział w wydarzeniach rozgrywających się na majdanach (placach) kraju również był reakcją na zewnętrzne bodźce mobilizacyjne, które jednak nie wywoływały niezadowolenia. Większość obywateli Ukrainy pojmuje swoje uczestnictwo w wydarzeniach pomarańczowej rewolucji jako świadomą walkę w obronie swoich praw, przede wszystkim związanych z procesem wyborczym. Pozwala to określić formy uczestnictwa politycznego obywateli w procesie wyborczym 2004 r. jako rodzaj protestu wyborczego, który uległ radykalizacji pod wpływem sfałszowania wyników głosowania w drugiej turze wyborów. Nie należy jednak umniejszać znaczenia najnowszych technologicznych i komunikatywno-informacyjnych środków mobilizacji obywateli, co generalnie dało efekt wszechobecności idei pomarańczowej rewolucji, ich rozpowszechnienia wśród znacznej, demokratycznie zorientowanej części elektoratu.

Jednakże w ocenie współzależności pierwiastka organizacyjnego i żywiołowości większość obywateli Ukrainy skłonna jest uważać, że w pomarańczowej rewolucji czynniki zaplanowane dominowały nad żywiołowymi. W szczególności 25,2\% przychyla się do poglądu, że protest wyborczy był akcją po części zorganizowaną, po części żywiołową, 23,9\% - akcją raczej zorganizowaną aniżeli żywiołową, 33,5\% - akcją całkowicie zorganizowaną. Jednocześnie 33,3\% obywateli definiuje istotę pomarańczowej rewolucji jako świadomą walkę obywateli, którzy zjednoczyli się w obronie swoich praw, $11,8 \%$ - jako żywiołowy protest ludności, podczas gdy czołową rolę opozycji w tych wydarzeniach wskazuje tylko $12,4 \%$ respondentów ${ }^{21}$. Ważne jest również to, że w ocenie charakteru organizacji wystąpień obywateli podczas wyborów 2004 r. nie ma respondentów, którzy w odpowiedzi nie określiliby swojego stanowiska, wszyscy operowali wyraźnie ukształtowanymi i zniuansowanymi opiniami na temat wydarzeń. Tak więc obywatele określili siebie jako główny podmiot wyborczego etapu cyklu wyborów prezydenckich.

Ogólnie rzecz biorąc, pomarańczowa rewolucja sformowała nowe doświadczenie uczestnictwa wyborczego, zarysowała nowe formy aktywności politycznej, stała się dowodem na udaną mobilizację stosunkowo dużej liczby obywateli Ukrainy, która była stymulowana przez wymuszoną konsolidację poszczególnych segmentów elity politycznej. Obywatele wybrali dla siebie aktywne formy protestacyjnej partycypacji wyborczej, co stało się dla nich narzędziem zmiany potrzeb i dążeń w sferze polityki. Właśnie aktywne uczestnictwo w tym etapie cyklu wyborczego sprzyjało przezwyciężeniu stereotypowego wyobrażenia, że polityka publiczna to sprawa innych, bardziej przygotowanych do tego ludzi. To właśnie wybory prezydenckie z 2004 r. zracjonalizowały model wyborczy uczestnictwa politycznego obywateli Ukrainy, co z czasem znalazło potwierdzenie w przebiegu kampanii wyborczych w latach 2006-2014.

21 Н. Паніна, Українське суспільство 1994-2005. Соиіологічний моніторинг, Київ 2005, s. 149. 
Charakterystyczną cechą uczestnictwa wyborczego obywateli Ukrainy w wyborach prezydenckich 2014 r. było to, że kontekst wyborów był określanym mianem przełomowego (podobnie jak wybory 1991 r.). Głównym motywem udziału w wyborach był, zdaniem wyborców, ich obywatelski obowiązek (57\%), następne pod względem znaczenia było pojmowanie wyborów jako możliwości wpłynięcia na sytuację na Ukrainie (26,5\%) i obawa, że - w razie jeśli nie wezmą udziału w głosowaniu - ich głos może zostać wykorzystany do sfałszowania wyborów (23,5\%). Szczególnie ważny, naszym zdaniem, jest fakt, że główne motywy głosowania na liderów kampanii wyborczej były następujące: 1 ) ,widzi realne sposoby przezwyciężenia kryzysu ekonomicznego i zapewnienia rozwoju ekonomicznego kraju" (52\% zwolenników P. Poroszenki, 56\% J. Tymoszenko); 2) „poglądy i propozycje są bliskie jego wyborcom” (49\% zwolenników P. Poroszenki, 56\% J. Tymoszenko), 3) „potrafi zjednoczyć obywateli wszystkich regionów i przezwyciężyć podział Ukrainy" (34\% zwolenników P. Poroszenki, 50\% J. Tymoszenko) ${ }^{22}$.

Specyfiką partycypacji wyborczej obywateli Ukrainy w 2014 r. stało się również to, że wybory odbywały się w warunkach nieogłoszonej wojny z Rosją, co do pewnego stopnia konsolidowało społeczeństwo ukraińskie i uniemożliwiło użycie środków administracyjnych i falsyfikacji. Ukształtowało to także szereg oczekiwań obywateli uważających, że pierwszymi krokami P. Poroszenki na stanowisku prezydenta powinny być: stabilizacja sytuacji na wschodzie, udane przeprowadzenie ATO [operacji antyterrorystycznej - przyp. tłum.]; bezzwłoczne przeprowadzenie reform; wsparcie przeprowadzenia przedterminowych wyborów do Rady Najwyższej Ukrainy i podpisanie ekonomicznej części Umowy stowarzyszeniowej z UE ${ }^{23}$. Określone zawyżone oczekiwania ludzi odnośnie do szybkich pozytywnych zmian w połączeniu z trudnościami w tworzeniu efektywnej i fachowej ekipy, zewnętrzną agresją i szantażem ze strony Rosji mogą stanowić główne zagrożenia dla działań P. Poroszenki jako prezydenta.

Podsumowując ocenę modelu wyborczego uczestnictwa politycznego, dodajmy, że treść decyzji wyborczych obywateli Ukrainy w roku 1991, 1994, 1999, 2004, 2010 i 2014 jest w istotnym stopniu różna. Jeśli głosowanie podczas wyborów prezydenckich 1991 r. można ocenić raczej jako ekspresyjne, to późniejsze kampanie wyborcze odbywały się na tle pewnego przyswojenia sobie reguł demokratycznego procesu politycznego i mechanizmów racjonalnego myślenia politycznego. Naszym zdaniem decyzje obywateli Ukrainy podejmowane podczas wyborów prezydenckich w roku 1994, 2004 i 2014 można określić jako egocentryczne i perspektywiczne, w odróżnieniu od wyborów 1999 r., kiedy motywacja uczestnictwa wyborczego kształtowała się w wymiarze socjotropicznym i retrospektywnym.

22 Вибори-2014: сподівання громадян, рейтинги кандидатів, мотивація вибору, ФонА „Аемократичні ініціативи імені Іیька Кучеріва”, [online] http://dif.org.ua/ua/publications/press-relizy/ jlvklvlvllvm.htm.

23 Експертне опитування „Вибори-2014: сподіване і несподіване”, ФонА „Аемократичні ініціативи імені Іцька Кучеріва”, [online] http://dif.org.ua/ua/publications/press-relizy/nktgnkejnrkhjnkejrhk. htm. 


\section{MODEL PROTESTACYJNY UCZESTNICTWA POLITYCZNEGO OBYWATELI UKRAINY W OKRESIE MIĘDZY WYBORAMI: SPECYFIKA KSZTAŁTOWANIA I EWOLUCJI}

Protest polityczny to zorganizowany sprzeciw obywateli wobec systemu politycznego, oficjalnego kursu politycznego, decyzji politycznych, który realizuje się za pomocą metod odpowiadających zaktualizowanym żądaniom. Władza zawsze postrzega masowy, nawet konwencjonalny protest polityczny jako niepożądany przejaw aktywności obywatelskiej, destabilizujący życie polityczne i ekonomiczne. Instytucjonalnym tłem rozwoju protestacyjnych form uczestnictwa politycznego obywateli i ich wpływu na polityczną dynamikę społeczeństwa jest proces kształtowania się oraz specyfika funkcjonowania opozycji politycznej. Jeśli cele opozycji w idealnym wariancie powinny konkretyzować modele rozwoju społecznego alternatywne w stosunku do modelu władzy, natomiast realnie mają charakter sytuacyjny, to masowa aktywność polityczna staje się jednym ze środków osiągnięcia tych celów. Charakter takiej masowej aktywności politycznej pod wieloma względami jest określany przez strategię, którą opozycja wybiera dla osiągnięcia własnych celów. To może być strategia odejścia (exit) albo matych spraw; strategia protestu (voice), czyli masowej mobilizacji obywateli na wszystkich etapach cyklu wyborczego; strategia lojalności (loyalty) - prowadzenie targów politycznych z grupą rządzącą i stopniowa inkorporacja w szeregi władz. Dość umownie proces instytucjonalizacji opozycji na Ukrainie można podzielić na cztery podstawowe etapy, z których każdemu odpowiada ta czy inna strategia działalności.

\section{ETAP CENTROPRAWICOWY (LATA 1989-1994)}

Na tym etapie opozycja wybrała strategię odejścia (matych spraw), kiedy narodowi demokraci, inkorporując się do władz, jednocześnie pozostawili sobie prawo do krytykowania ich. Takie stanowisko sił opozycyjnych nie sprzyjało akumulacji w ramach tej instytucji systemu politycznego potencjału protestacyjnego obywateli i jego transmisji poza obręb Rady Najwyższej Ukrainy. Przemiany polityczne w latach 1991-1993 nie doprowadziły do głębokich transformacji systemu politycznego Ukrainy, lecz adaptacji istniejącego w ZSRS ustroju politycznego, co nie sprzyjało kardynalnym zmianom charakteru i ukierunkowania realizowania władzy politycznej. Dlatego też po niedługim okresie euforii lat 1991-1993 w społeczeństwie ukraińskim zaczął narastać kryzys zaufania do już nowych - demokratycznych - instytucji systemu politycznego. Naszym zdaniem na Ukrainie tracono czas, gdy protest ekonomiczny obywateli można było przenieść na płaszczyznę protestu politycznego w celu przyspieszenia transformacji systemowych w ekonomicznej i politycznej sferze funkcjonowania społeczeństwa. Po pierwsze, było to uwarunkowane tym, że tradycyjnie potencjał ekonomiczny protestu obywateli akumulują i transmitują organizacje związkowe, które wówczas na Ukrainie zajmowały stanowisko prorządowe, a niezależne związki zawodowe znajdowały się w początkowym 
stadium instytucjonalizacji. Po drugie, upolityczniać niezadowolenie ekonomiczne mogłyby partie o lewicowej orientacji (jednakże SPU [Socjalistyczna Partia Ukrainy przyp. tłum.] nie była zainteresowana tymi procesami, działalność KPU [Komunistycznej Partii Ukrainy - przyp. tłum.] została zakazana) lub partie o orientacji narodowo-patriotycznej, które z kolei aktywnie starały się inkorporować w struktury władzy. Po trzecie, elita ukraińska wówczas dopiero zaczęła uświadamiać sobie zjawisko zapotrzebowania na opozycję jako instytucję systemu politycznego, który akumuluje i reprezentuje wobec władzy niezadowolenie obywateli z polityki rządu. Tak więc na Ukrainie nie sformowała się żadna siła instytucjonalna zdolna wpływać na proces kształtowania i użycia przez obywateli protestacyjnych modeli uczestnictwa politycznego w okresie pomiędzy wyborami, jednakże to właśnie ona jest centralnym czynnikiem w określeniu protestacyjnego potencjału obywatela i społeczeństwa jako takiego.

Biorąc pod uwagę brak skutecznej opozycji systemowej, w sytuacji kryzysu ekonomicznego, hiperinflacji, niezdolności władzy do realizowania efektywnych przekształceń w gospodarce oraz konserwowania sprzeczności politycznych i ekonomicznych miało miejsce żywiołowe upolitycznianie ekonomicznego niezadowolenia, realizujące się $\mathrm{w}$ praktyce poprzez niesystemowe wystąpienia-protesty obywateli Ukrainy. Najbardziej znaczący wpływ na politykę rządową miały akcje protestacyjne górników na początku lat 90. Niedostateczne zainteresowanie polityczne władz kraju potrzebą przeprowadzenia radykalnych strukturalnych reform ekonomicznych doprowadziło do katastrofalnych skutków, przede wszystkim w kapitałochłonnych branżach produkcji, i stało się przyczyną protestacyjnych wystąpień górników, którzy biorąc pod uwagę własną szczególną rolę w przebiegu transformacji, łączyli żądania ekonomiczne z politycznymi. Upolitycznianiu ekonomicznego niezadowolenia sprzyjał również dość wysoki poziom biernej aktywności politycznej, charakterystycznej w latach 1990-1993 dla wschodnich regionów Ukrainy, gdzie regularnie o polityce czytało $58 \%$ obywateli, omawiało problemy polityczne $-62 \%$, podczas gdy $\mathrm{w}$ potencjalnie aktywnym regionie zachodnim robiło to, odpowiednio, $33 \%$ i $32 \%$ obywateli ${ }^{24}$. Akcja strajkowa nieprzypadkowo rozprzestrzeniła się właśnie na wschodzie Ukrainy, tutaj bowiem właśnie największy był odsetek obywateli, dla których głównym motywem udziału w wystąpieniach protestacyjnych było obniżenie stopy życiowej: 57\% górników uważało strajk z żądaniami ekonomicznymi za normalną formę protestu, 36\% reprezentowało przeciwstawny punkt widzenia. Na zachodzie Ukrainy głównymi motywami użycia protestacyjnych form uczestnictwa politycznego była obrona niepodległości i integralności terytorialnej Ukrainy (62\%) oraz demokracji i praw człowieka (54\%), podczas gdy motywy o charakterze ekonomicznym, chociaż były istotne dla $52 \%$, jednakże w hierarchii motywacji zajmowały trzecie miejsce ${ }^{25}$. Jednak i na wschodzie, i na zachodzie kraju jako cel protestu ekono-

24 Е. Головаха, Политическая информированность, компетентность и активность населения, [w:] tenże, Политическая культура населения Украины. Результать сочиологических исследований, Київ 1993, s. 26. 
micznego postrzegana była bardziej efektywna ochrona socjalna ludności, a nie przyspieszenie reform ekonomicznych i politycznych.

Strategia ignorowania strajków o charakterze ekonomicznym, które realnie nie zagrażały istniejącemu systemowi politycznemu, zahamowała kształtowanie protestacyjnego modelu uczestnictwa politycznego obywateli Ukrainy, którzy w zastosowaniu konwencjonalnego protestu nie dostrzegali skutecznego mechanizmu wpływania na instytucje władzy. Stopniowo górnicze protesty wygasały nabierając charakteru lokalnego, przeważnie w obwodach donieckim i ługańskim.

\section{ETAP CENTROLEWICOWY (LATA 1994-1999)}

W drugim etapie opozycja wybrała strategię lojalności (loyalty) - prowadzenie sporu z grupą rządzącą i stopniowej inkorporacji w struktury władzy. Skutkiem tej strategii stało się obniżenie politycznej gotowości obywateli Ukrainy do protestu w okresie międzywyborczym i osłabienie instytucji opozycji, przejawiające się w braku zbieżności między gtoszonymi zasadami politycznymi a konkretnym zachowaniem polityków ${ }^{26}$. Proces kształtowania się opozycji politycznej w tym okresie był obciążony faktem, że w Konstytucji z 1996 r. nie zostały określone zasady jej tworzenia i funkcjonowania. Doprowadziło to do ukształtowania dyspersyjnej legalności opozycji, której działalność nie opiera się na wyraźnie sformułowanych założeniach konstytucyjnych działania alternatywnego wobec istniejącej władzy, której prawa nie są wyraźnie opisane, a istota jest nieokreślona. Wskutek obniżenia poziomu średniej płacy u większej części ludności obniżył się poziom zadowolenia z życia. Dla kształtowania orientacji protestacyjnej wskaźnik ten ma niekiedy znaczenie decydujące, ponieważ, po pierwsze, poczucie własnego dobrobytu odbija się na stosunku obywatela do sfery polityki; po drugie, w odróżnieniu od zadowolenia z funkcjonowania instytucji politycznych, które zawsze związane jest z bieżącą koniunkturą i dlatego nie trwa długo, przychylność obywateli do idei demokracji ma bardziej istotne podłoże - ekonomiczne. Jednak obniżenie stopy życiowej obywateli Ukrainy nie stało się podstawą dla masowego protestu politycznego, aczkolwiek było ono głównym czynnikiem napięć społecznych w ukraińskim społeczeństwie. W 1996 r. tylko 2\% obywateli chciało uczestniczyć w wiecach i demonstracjach protestu, po $1 \%$ - w strajkach, pikietach i blokowaniu gmachów organów władzy państwowej, w zastosowaniu różnych form niekonwencjonalnego protestu ${ }^{27}$. W pewnym stopniu świadczy to o zachowaniu w świadomości masowej nastrojów etatystycznych, które nie pobudzają obywateli do protestów przeciwko państwu.

Naszym zdaniem należy do tego dodać jeszcze dwa aspekty, które pozwolą pogłębić rozumienie kształtowania protestacyjnego modelu politycznego uczestnictwa obywa-

26 Э. Уиясон, Новая виртуальная политика Украиньь, „Конституционное право. Восточноевропейское обозрение" 2001, nr 3, s. 35.

27 В. Кремень і іп., Соціально-політична ситуація в Україні. Поступ п'sти років. Монографія, Київ 1996, s. 84. 
teli w procesach transformacji okresu przejściowego. Po pierwsze, protestacyjne uczestnictwo polityczne nie może powtarzać się automatycznie w ciągu niedługiego czasu. Ma ono charakter cykliczny, który strukturalnie dzieli się na etap wzrostu, kryzysu, upadku i depresji. Przy czym w wymiarze czasowym pierwszy etap jest zawsze najkrótszy w porównaniu z trzema następnymi. Po drugie, obywatele - potencjalnie skłonni do wykorzystywania protestacyjnych form uczestnictwa politycznego - w ostatniej chwili rezygnują z tego, ponieważ uważają, że problem może zostać rozwiązany poprzez wykorzystanie zasobów innych obywateli, którzy realnie wezmą udział w akcjach protestu politycznego. Uzyskanie pozytywnego politycznego wyniku pozwoli im zaoszczędzić własne zasoby i rozwiązać problem przy wykorzystaniu zasobów innych.

Tak więc w latach 1994-1999 strajki, wiece i demonstracje, które miały podłoże ekonomiczne, stały się zwykłą sprawą zarówno dla obywateli Ukrainy, jak i dla władzy. Jednakże reakcja władzy na żądania protestujących była minimalna, przede wszystkim z powodu przekonania o nieograniczonej cierpliwości ludności kraju i braku skutecznej opozycji systemowej. W dodatku władza, która nie miała wyraźnego zabarwienia ideologicznego, mogła manipulować ocenami wystąpień protestacyjnych formułowanymi przez różne partie polityczne. Partie prawicowe nie popierały pomysłu przeprowadzenia masowych akcji protestu, ponieważ mityngujący mieli możliwość formułowania politycznych haseł, które na wschodzie Ukrainy nabierały charakteru destruktywnego dla idei państwowości. Lewicowi przeważnie inicjatorzy protestacyjnych wystąpień obywateli niemal każdą akcję starali się nasycić żądaniami o charakterze ściśle politycznym, a nie przekształcać żądania ekonomiczne w przedmiot dyskursu władzy. Jednak deklarowana przez KPU opozycyjność nie kojarzyła się obywatelom z realną alternatywą wobec oficjalnego kursu politycznego, a sama partia nie utożsamiała się z tą siłą polityczną, która potrafi przybliżyć potencjał protestu niezadowolonych obywateli do płaszczyzny realnych stosunków politycznych. Dlatego też władza przeważnie ignorowała protestacyjne wystąpienia obywateli, obawiając się, że stworzy sobie wroga bądź w postaci sił lewicowych, bądź w postaci sił prawicowych. Brak reakcji struktur władzy w końcu ukształtował u większości obywateli Ukrainy wyraźne wyobrażenie o tym, że konwencjonalne formy protestu politycznego nie są w stanie wpłynąć na politykę rządu.

\section{ETAP EKLEKTYCZNY (GRUDZIEŃ 1999-2004)}

$\mathrm{Na}$ tym etapie instytucjonalizacji opozycja wybrała strategię protestu (voice), czyli masowej mobilizacji obywateli w okresie międzywyborczym. Po raz pierwszy na Ukrainie opozycja systemowa przedsięwzięła próbę przeniesienia protestacyjnego potencjału uczestnictwa wyborczego na płaszczyznę realnego protestu w okresie między wyborami (długotrwała akcja „Ukraina bez Kuczmy!” / „Powstań, Ukraino!”). Specyfika postrzegania przez władzę opozycji jako wroga politycznego, a nie oponenta odbiła się na określeniu roli i istoty tej instytucji politycznej przez obywateli Ukrainy.

Podkreślmy, że potencjał protestacyjny społeczeństwa ukraińskiego podczas akcji UBK [„Ukraina bez Kuczmy” - przyp. tłum.] był dość wysoki. W 2000 r. - 25,4\%, 
a w 2001 r. - 29,7\% obywateli było gotowych osobiście wziąć udział w akcjach prote$\mathrm{stu}^{28}$. Jednak realnie protestacyjne formy uczestnictwa politycznego wykorzystywała znacznie mniejsza liczba obywateli. W pierwszym etapie akcję UBK popierało od 42 do $46 \%$ obywateli Ukrainy ${ }^{29}$. Wraz z jej rozwojem coraz większy odsetek obywateli wyraźnie określał swoje stanowisko polityczne (w maju o 5,8\% więcej niż w lutym), równocześnie zmniejszała się (o 0,8\%) liczba tych, którzy w ogóle nic o niej nie słyszeli. Większość (31\%) przychylała się do zdania, że przeprowadzanie podobnych akcji to jedyna szansa na obalenie reżimu L. Kuczmy, jednakże rola opozycji w niej była określana albo jako przejaw destruktywnych nastrojów sił opozycyjnych, jej chęć przejęcia władzy na drodze konstytucyjnej (16\%), albo jako potwierdzenie tego, że wyczerpała ona wszystkie inne możliwości rozwiązania problemów społecznych (19\%). Oceniając pozytywnie zainicjowane przez opozycję akcje protestu politycznego, obywatele postrzegali swoją rolę w nich jako ostatni wariant działań opozycji.

$\mathrm{Z}$ czasem, ze względu na strategiczne błędy opozycji, potencjał protestu spadał i przestał być krytyczny dla władzy. Jednakże, prognozując rozwój wydarzeń w kraju, tylko $20 \%$ obywateli Ukrainy uważało, że L. Kuczma nadal będzie pełnił swoje obowiązki, reszta popierała różne warianty pozbawienia go prezydenckich uprawnień: $28 \%$ uważało, że L. Kuczma sam poda się do dymisji; $11 \%$ - że odbędzie się referendum na temat konieczności przeprowadzenia przedterminowych wyborów prezydenta; $9 \%$ - że Rada Najwyższa Ukrainy zainicjuje i doprowadzi do końca procedurę impeachmentu; 6\% - że Rada Najwyższa Ukrainy i opozycja potrafią wymóc przeprowadzenie przedterminowych wyborów prezydenta Ukrainy. Z ogólną liczbą obywateli Ukrainy, którzy popierali pomysł akcji UBK, koreluje procent tych $(47,7 \%)$, którzy uważali za konieczną dymisję szefa SBU [Służby Bezpieczeństwa Ukrainy przyp. tłum.] L. Derkacza, ministra spraw wewnętrznych Ukrainy J. Krawczenki i szefa DMSU [Państwowej Służby Migracyjnej Ukrainy - przyp. tłum.] J. Sołowkowa ${ }^{30}$. Wszystko to świadczy o szerzeniu się w społeczeństwie nastrojów opozycyjnych, które z łatwością mogłaby zakumulować skuteczna, strukturalnie homogeniczna opozycja polityczna. Jednak takiej opozycji, jak też lidera uznanego przez społeczeństwo i samą opozycję w ukraińskiej przestrzeni politycznej wówczas nie było. I tak np. 49\% obywateli Ukrainy uważało, że trudno jest określić osobę lidera opozycji, a 15\% uzyskane przez J. Tymoszenko (lidera tego rankingu) ${ }^{31}$ nie wystarczało do tego, by mogła ona zakumulować nastroje opozycyjne i stać się figurą jednoczącą w strukturze opozycji.

Regionalne modele protestacyjnego uczestnictwa politycznego obywateli Ukrainy kształtowały się pod wpływem ich ideologicznych przekonań, ocen działalno-

\footnotetext{
28 Н. Паніна, Украӥнське суспільство 1994-2005..., s. 39.

29 Політична криза в Україні: еволючія та головні уроки, „Політичний календар. Інформаційно-анамітичний огмяА” 2001, nr 6, s. 56-63.

30 Аумка киян та експертів про подї̈ в Україні, „Політичний календар. Інформаційно-аналітичний огмяА" 2001, nr 1, s. 45.

31 Політична криза в Україні..., s. 62.
} 
ści władz centralnych i regionalnych, poziomu lojalności tej ostatniej wobec masowych akcji protestu. Naszym zdaniem można mówić o trzech regionalnych modelach uczestnictwa politycznego obywateli Ukrainy w systemowym proteście w latach 2000-2003. Istota zintegrowanego modelu protestacyjnego uczestnictwa politycznego, który ukształtował się w zachodnich regionach Ukrainy i przybrał najbardziej jaskrawe formy w obwodach lwowskim i tarnopolskim, polega na pozytywno-neutralnym sprzyjaniu miejscowej władzy uczestnikom akcji protestacyjnej, co jest uwarunkowane przenikaniem (integracją) idei protestu do władz miejscowych organów władzy państwowej oraz do administracji. Aktywistyczny model protestu politycznego uczestnictwa sformował się w twardym konflikcie z miejscowymi organami władzy i przewidywał kategoryczną obronę przez obywateli swoich poglądów politycznych. Najpełniej został on zrealizowany w obwodzie czerkaskim, który stał się do pewnego stopnia wyjątkiem na politycznej mapie Ukrainy, ponieważ czerkaskie miasteczko namiotowe zwyciężyło w trzytygodniowym konflikcie ze strukturami siłowymi. Główną cechą kontrowersyjno-pesymistycznego modelu protestu politycznego jest znaczący rozziew między potencjalnym i realnym protestem obywateli, którego źródłem są nastroje paternalistyczne i bierne uznanie priorytetu władzy nad potrzebami i wartościami człowieka. Jego kształtowanie się miało miejsce na tle totalnego rozpowszechnienia ocen władzy odnośnie do istoty oraz celu organizowania przez opozycję protestacyjnych wystąpień obywateli.

Tak więc już początek antyreżymowych wystąpień protestacyjnych obywateli, zorganizowanych przez eklektyczną opozycję, potwierdził niedokończenie kształtowania się efektywnego modelu protestacyjnego uczestnictwa politycznego, który przewiduje, że jego inicjatorzy i uczestnicy ogłaszają zakończenie akcji wystąpień protestacyjnych dopiero po osiągnięciu celu protestu albo zawarcia kompromisu względem przedmiotu protestu. Biorąc pod uwagę znaczący rozziew między potencjalnym i realnym protestem, model wystąpień protestacyjnych obywateli pod przewodem opozycji określamy jako model protestu deklaratywnego, opartego na scenariuszowym projektowaniu działań politycznych.

\section{ETAP PRAGMATYCZNY (2005 R. - DO DZIŚ)}

Etap ten cechuje wykorzystanie strategii odejścia (exit) albo matych spraw. Jednakże jeśli w latach 1989-1994 uciekanie się do tej strategii miało do pewnego stopnia charakter wymuszony, to na danym etapie był to świadomy, racjonalny wybór, który jest dowodem na zdystansowanie się sił opozycyjnych wobec działań i polityki władzy. Należy zauważyć, że w okresie od 2005 r. do września 2014 r. opozycja na Ukrainie nie uciekała się do prób organizowania wystąpień protestacyjnych na wielką skalę z wyraźnie przemyślanym scenariuszem, logiką i ukrytym przed społeczeństwem celem. Według wyników monitoringu Centrum Badania Społeczeństwa (okres przeprowadzenia monitoringu: wrzesień 2009 r. - grudzień 2010 r.) wzrost aktywności protestacyjnej obywateli Ukrainy przypada na okres po wyborach prezydenckich 2010 r.: od marca do 
czerwca. W tym czasie największa aktywność protestacyjna cechowała obwody kijowski, odeski, lwowski, charkowski oraz Krym. Do najspokojniejszych należały obwody: kirowogradzki, sumski, zakarpacki i rówieński.

Najbardziej rozpowszechnioną tematyką działań protestacyjnych na Ukrainie były właśnie sprawy społeczno-ekonomiczne (55,8\%), takie jak prawa robotników (zwłaszcza opóźnienia w wypłacie pensji), konflikty związane z planami zabudowy terenów, wyrzucaniem ludzi z hoteli pracowniczych, protesty ekologiczne oraz walka o prawa drobnych przedsiębiorców. Protesty w obronie praw drobnych przedsiębiorców przed wrześniem 2010 r. nie miały jednego albo kilku ognisk konfliktu: 9,9\% akcji protestacyjnych odbyło się w obwodzie odeskim, 9,2\% - w czerkaskim, 8,5\% - na Krymie, w obwodach kijowskim i połtawskim, 7,1\% - w obwodzie zaporoskim; w innych obwodach również odbywało się po kilka akcji protestacyjnych. $87,2 \%$ działań odbywało się przy współudziale przedstawicieli małego biznesu, 20,6\% - przy współudziale lokalnych związków zawodowych i stowarzyszeń przedsiębiorców. W 13,5\% przypadków do protestów przyłączały się partie czy politycy, przede wszystkim OZ „Swoboda” i „Front Zmian”. Zresztą, „Swoboda”, która pozycjonuje się jako obrońca małego biznesu, wzięła udział zaledwie w ośmiu akcjach protestacyjnych, z których cztery odbyły się w ciągu jednej akcji przeciwko zamknięciu rynku w Czerniowcach na okres kwarantanny, a kolejne dwie miały miejsce z powodu wywierania presji na członka tej partii w związku z jego działalnością gospodarczą.

Po wyborach 2010 r. zaostrzyły się protesty ideologiczne (19,3\%), które dotyczyły przede wszystkim tradycyjnych tematów stosunku do sowieckiej historii, OUN-UPA i innych zagadnień nacjonalizmu ukraińskiego. „Oddolna” polityka pamięci stanowiła przedmiot ponad połowy $(55,1 \%)$ protestów związanych z konfliktami ideologicznymi i określeniem tożsamości regionalnej. Pod względem tematyki poruszanej w działaniach protestacyjnych wyodrębniały się następujące kategorie „oddolnej” polityki pamięci: protesty prokomunistyczne, które utwierdzały sowiecką wersję historii Ukrainy lub jej broniły; protesty antykomunistyczne, które rzucały wyzwanie sowieckiej wersji historii; inne protesty, niezwiązane bezpośrednio z interpretacją działań władzy sowieckiej - m.in. akcje wokół stawiania pomników działaczom imperium rosyjskiego lub z żądaniem uznania ludobójstwa Ormian w Turcji.

Stopniowy, lecz systematyczny powrót na Ukrainie do autorytarnego, a czasami też ujawniającego poszczególne cechy totalitarnego modelu zarządzania politycznego, który bazuje na praktykach manipulacyjnych i nie przewiduje uwzględniania interesów i potrzeb obywateli, wywołał szereg wydarzeń politycznych, określanych ogólną nazwą Majdan lub rewolucja godności. Główną przyczyną zapoczątkowania rewolucji godności była odmowa przez W. Janukowycza podpisania Umowy stowarzyszeniowej z UE (Majdan-Wiec). Krwawe rozpędzenie protestów pokojowych nie powstrzymało Ukraińców, lecz popchnęło ich do użycia bardziej różnorodnych form protestu politycznego, umownie połączonych nazwą Majdan-Obóz. Brak adekwatnych decyzji politycznych ze strony władzy sprzyjał organizacyjnemu ukształtowaniu się protestu pod postacią działającego permanentnie Majdanu-Siczy. Przeanalizujmy dynamikę motywacji i żądań protestu politycznego obywateli Ukrainy w organizacyjnych formach 
Majdanu-Wiecu, Majdanu-Obozu i Majdanu-Siczy oraz ich stosunku do różnych mechanizmów wyjścia z kryzysu politycznego.

\section{MOTYWACJA UCZESTNICTWA}

Wśród motywów, które pobudzały ludzi do masowego wyjścia na Majdan-Wiec, trzema najbardziej powszechnymi były: brutalne pobicie demonstrantów na Majdanie w nocy na 30 listopada 2013 r. i represje (70\%), rezygnacja W. Janukowacza z podpisania Umowy stowarzyszeniowej z Unią Europejską (53,5\%) oraz dążenie do zmiany życia na Ukrainie (50\%). Dobrze wyrażone były również żądania zmiany władzy na Ukrainie (39\%). Apele opozycji były bodźcem dla 5\% uczestników, co potwierdza przedstawione powyżej tendencje świadczące o minimalnym wpływie opozycji na organizację wystąpień protestacyjnych, tyle samo ludzi też wyszło na Majdan, pragnąc zemścić się na władzy za jej działania. Symptomatyczny jest też fakt, że $92 \%$ uczestników Majdanu nie należało do żadnej partii politycznej, organizacji społecznej czy ruchu ${ }^{32}$.

Majdan-Obóz stał się permanentnie funkcjonującą formą protestu politycznego, jednakże w sobotę i niedzielę nabierał również cech Majdanu-Wiecu. Motywy, które skłaniały obywateli nie tylko do wyjścia na Majdan, lecz także do pozostania tam, są podobne do motywacji uczestnictwa w Majdanie-Wiecu. Przede wszystkim jest to brutalne pobicie demonstrantów na Majdanie w nocy na 30 listopada i represje (69\%), rezygnacja W. Janukowycza z podpisania Umowy stowarzyszeniowej z Unią Europejską (40\%), dążenie do zmiany władzy na Ukrainie (39\%) oraz pragnienie zmiany życia na Ukrainie (36\%). Apele opozycji były bodźcem już dla 7\% uczestników, motyw zemsty na władzy za wszystko, co ona wyprawia dla 10\%, czyli dwukrotnie więcej aniżeli wśród uczestników Majdanu-Wiecu ${ }^{33}$.

Majdan-Obóz w ciągu pierwszego miesiąca funkcjonowania stopniowo przekształcił się na Majdan-Sicz, który trwał w ciągłym oczekiwaniu na atak i stał się bardziej zamknięty dla osób postronnych. Motywy, które pobudzały ludzi nie tylko do wyjścia na Majdan i rozbicia tam obozu, lecz także do stworzenia dość dobrze zorganizowanej struktury w postaci Majdanu-Siczy, są takie same jak te, które były charakterystyczne dla uczestników Majdanu-Wiecu i Majdanu-Obozu: brutalne represje władzy wobec uczestników protestów (61\%), „dążenie do zmiany życia na Ukrainie” (51\%, było - 36\%), rezygnacja W. Janukowycza z podpisania Umowy stowarzyszeniowej z Unią Europejską (47\%) i chęć zmiany władzy na Ukrainie (46\%). Na apele opozycji stanowiącej część Majdanu-Siczy reagowało już tylko 3\%, demonstrując tym samym brak zaufania do zinstytucjonalizowanych form stosunków władzy i konwencjonalnych rodzajów uczestnictwa politycznego, a chęć zemsty na władzy za wszyst-

\footnotetext{
Майдан-2013: xmo cmoїmь, чому і за шо?, ФонА „Аемократичні ініціативи імені Іиька Кучеріва”, [online] http://dif.org.ua/ua/polls/2013-year/mogjorjghoeoj.htm.

33 Майдан-мітинг і Майдан-табір: схоже і відмінне, ФонА „Аемократичні ініціативи імені Іیька Кучеріва”, [online] http://dif.org.ua/ua/polls/2013-year/vjweojgvowerjoujgo.htm.
} 
kie jej działania nie przekraczała stabilnych $10 \%$. Jednak z rozwojem wydarzeń wśród uczestników Majdanu-Siczy w większym stopniu rozpowszechnił się taki motyw, jak poczucie zagrożenia, że Ukraina przyłączy się do Unii Celnej czy też w ogóle wróci do Rosji (z 14\% do 20\%) $)^{34}$.

\section{ŻĄDANIA PROTESTUJĄCYCH}

Wśród głównych żądań, które wysuwano na Majdanie, największe poparcie wśród protestujących zyskały żądania zwolnienia aresztowanych uczestników Majdanu (50,2\%), wstrzymania represji (82\%), dymisji rządu (80\%), dymisji W. Janukowycza i przeprowadzenia przedterminowych wyborów prezydenckich (75\%), podpisania Umowy stowarzyszeniowej z Unią Europejską (71\%), wszczęcia procesów karnych wobec winnych pobicia demonstrantów na Majdanie (58\%), rozwiązania Rady Najwyższej i rozpisania przedterminowych wyborów parlamentarnych (56\%). Poza tym znaczna część uczestników Majdanu wypowiedziała się za wszczęciem procesów karnych wobec wszystkich, którzy byli zamieszani w korupcję (50\%), za ogólnym podniesieniem poziomu życia ludności (47\%), zwolnieniem J. Tymoszenko (38\%) i zmianą Konstytucji, powrotem do reformy konstytucyjnej 2004 r., która ograniczała władzę prezydenta $(38 \%)^{35}$.

Główne żądania Majdanu-Wiecu i Majdanu-Obozu są identyczne, jednak ich istotność jest nieco inna: uczestnicy Majdanu-Obozu na pierwszym miejscu stawiali żądania polityczne - dymisji rządu (74,5\%), dymisji W. Janukowycza i przeprowadzenia przedterminowych wyborów prezydenckich (66\%), a na trzecim miejscu zwolnienie aresztowanych uczestników Majdanu, wstrzymanie represji (64\%), podczas gdy dla uczestników Majdanu-Wiecu żądanie zwolnienia aresztowanych było najważniejsze $(82 \%)^{36}$.

W okresie trwania Majdanu-Siczy wyraźniej skoncentrowały się zasadnicze żądania, które protestujący uważali za główne i których nie można oceniać jako żądania systemowego protestu politycznego - dymisja W. Janukowycza i przeprowadzenie przedterminowych wyborów prezydenckich (85\%, wzrost o $20 \%$ ), a także zwolnienie aresztowanych uczestników Majdanu, wstrzymanie represji (82\%, wzrost o 20\%). Szczególną uwagę należy zwrócić na zmniejszenie siły żądania podpisania Umowy stowarzyszeniowej z Unią Europejską z $71 \%$ do 49\% ${ }^{37}$. Nie należy jednak, naszym zdaniem, traktować tego jako dowodu na rezygnację obywateli Ukrainy z wyboru kierunku eurointegracji. Uważamy, że wskazuje to raczej na zmianę orientacji z uwagi na konieczność rozwiązania problemów wewnątrzpolitycznych, przeformatowania systemu politycznego Ukrainy i zmiany zasad działalności elity politycznej.

34 Вiд Майдану-табору до Майдану-січі: що змінилося?, ФонА „Аемократичні ініціативи імені ІАька Кучеріва”, [online] http://dif.org.ua/ua/polls/2014_polls/vid-maidanu-taboru-do-maidan.htm.

35 Майдан-2013: хmо стоївь...

36 Майдан-мітинг і Майдан-мабір...

37 Вiд Майдану-табору до Майдану-січі... 


\section{MODELE WYJŚCIA Z KRYZYSU}

W ciągu całego okresu rewolucji godności w dyskursie politycznym aktywnie omawiane były szanse, mechanizmy i moduły wyjścia z kryzysu politycznego. Uczestnicy Majdanu-Wiecu (51\%) byli zorientowani na przeprowadzenie okrągłego stołu rokowań z udziałem władzy, opozycji i liderów społecznych przy pośrednictwie organizacji międzynarodowych, jednak 41,5\% negowało możliwość jakichkolwiek rokowań z władzą. Przy czym młodzież była bardziej skłonna do kompromisów (56\%) aniżeli ludzie w średnim (48\%) i starszym (48\%) wieku ${ }^{38}$. Uczestnicy Majdanu-Obozu byli mniej skłonni do poparcia procesu rokowań z władzą w porównaniu z Majdanem-Wiecem. 45\% uczestników Majdanu-Obozu zgadzało się na propozycję przeprowadzenia okrągłego stołu rokowań z udziałem władzy, opozycji i liderów społecznych przy pośrednictwie organizacji międzynarodowych, nie zgadzało się $-47 \%^{39}$. Sytuacja zmieniła się radykalnie wraz z utworzeniem Majdanu-Siczy - tylko 27\% jego uczestników uważało, że rokowania $\mathrm{z}$ władzą są potrzebne, a $63 \%$ było przeciwnych jakimkolwiek rokowaniom. Tylko $1 \%$ protestujących oceniał pozytywnie propozycję, by liderzy opozycji stanęli na czele rządu, $6 \%$ uważało, że można zgodzić się tylko na formowanie rządu w całości przez opozycję, a 22\% - że można to przeprowadzić tylko w razie powrotu do Konstytucji z 2004 r. i wzmocnienia roli premiera i rządu. Jednak $62 \%$ uważało, że dopóki prezydentem pozostawał będzie W. Janukowycz, nie można zgodzić się na jakikolwiek udział w rządzie ${ }^{40}$.

Przytoczone wyniki badań socjologicznych potwierdzają, że nawet w sytuacji kryzysu systemowego siły opozycyjne nie uciekły się do wykorzystania strategii protestu (voice), czyli masowej mobilizacji obywateli na wszystkich etapach cyklu wyborczego. Ich próby integracji z już zmobilizowaną przestrzenią obywatelską nie były na tyle udane, by stanęły na jej czele. Opozycja występowała tylko w roli partnera - być może nawet nierównoprawnego - społeczeństwa obywatelskiego, które w odróżnieniu od protestów pomarańczowej rewolucji, na razie pozostaje zmobilizowanym politycznie w różnych formach organizacyjnych (AutoMajdan, Demokratyczny Alians, Prawy Sektor, Społeczny Sektor EuroMajdanu i „EuroMajdan SOS”).

W tym kontekście ważne są opinie obywateli Ukrainy na temat wydarzeń na Majdanie. Akcje protestu EuroMajdanów ogólem popiera 50\% ludności, nie popiera - 42\%. Jednak ten stosunek jest różny w różnych regionach Ukrainy: protesty przeważnie cieszą się poparciem w regionie zachodnim (popieram - 80\%, nie popieram - 7\%) i regionie centralnym (odpowiednio: 63\% i 28\%), a przeważnie nie cieszą się poparciem na południu (popieram - 20\%, nie popieram - 71\%) i na wschodzie (odpowiednio: $30 \%$ i 65\%). W akcjach protestu na EuroMajdanach najbardziej aktywnie brali udział mieszkańcy regionu zachodniego - 26\%, regionu centralnego - 15\% (w Kijowie - 39\%), a w znacznie mniejszym stopniu mieszkańcy regionu południowego (5,5\%) i wschod-

\footnotetext{
38 Майдан-2013: хmо стоїmь...

39 Майдан-мітинг і Майдан-мабір...

40 Від Майдану-maбору до Майдану-січі...
} 
niego (3\%). Akcje AntyMajdanu przeważnie nie były popierane przez ludność Ukrainy (nie popieram 57\%, popieram 27\%). Jednak stosunek do tych akcji poparcia dla prezydenta i rządu był różny w różnych regionach Ukrainy: wyraźnie negatywny na zachodzie $(89 \%$ - nie popieram, $3 \%$ - popieram) i w centrum $(75 \%$ - nie popieram, $14 \%$ - popieram) i przeważnie pozytywny na południu (popieram - 54\%, nie popieram $-22 \%$ ) i na wschodzie (popieram - 43\%, nie popieram - 38\%). W akcjach AntyMajdanów brała udział znikoma część ludności Ukrainy: 0,6\% - na zachodzie, i prawie po 3\% w centrum, na południu i wschodzie. Mimo różnego stosunku do EuroMajdanów i AntyMajdanów ludność różnych regionów jest solidarnie zgodna co do tego, że niezbędne jest przeprowadzenie rozmów okrągłego stołu władzy i opozycji: zgadza się z tym $73 \%$ mieszkańców zachodu, $64 \%$ - centrum, $80 \%$ - południa i $78 \%$ - wschodu ${ }^{41}$.

Podsumowując wyniki badań wykorzystania przez obywateli Ukrainy modelu protestacyjnego uczestnictwa politycznego w latach 1991-2014, należy skonstatować, że ideologiczna nieokreśloność władzy na Ukrainie doprowadziła do utraty przez opozycję jej ideowego oblicza i politycznej wyrazistości, ponieważ partie polityczne, które uważały się za opozycyjne, zmuszone były do zajmowania skrajnego stanowiska wobec władzy popierały one jedne jej działania, usiłując je stymulować, jednocześnie przeciwstawiając się innym. Dla władzy jej ideologiczna nieokreśloność stanowiła bezwzględną przewagę, ponieważ pozwalała zdobywać sympatie obywateli o różnych, czasami przeciwstawnych orientacjach polityczno-ideologicznych. W tym samym czasie dla partii opozycyjnych, które są produktem zideologizowanej epoki nowoczesności, nastał kryzys tożsamości politycznej i ideologicznej, którego skutkiem jest utrata przez opozycję jej istotnych cech. Opozycyjność wszystkich partii politycznych na Ukrainie była tylko reakcją na działania władzy, pozbawioną samodzielnych alternatywnych programów polityczno-ideologicznych, zdolnych do uaktywnienia obywateli Ukrainy w dłuższym okresie.

\section{POLITYCZNY DYSKURS JAKO TECHNOLOGIA WŁADZY I OBYWATELI}

Wydarzenia końca 2013 r. - początku 2014 r. aktualizują konieczność wypracowania i wykorzystania dyskursywnego uczestnictwa politycznego. Fakt przekształcenia obywateli w zasób władzy - niestety, niekiedy pod względem cech zasób nawet nie tyle polityczny, co fizyczny - zachęca nas do szukania optymalnego modelu uczestnictwa politycznego obywateli w międzywyborczym dyskursie politycznym.

Obywatele Ukrainy dysponują takim doświadczeniem (proces konstytucyjny w latach 1992-1996, omawianie reformy politycznej 2002 r., dyskusje wokół reformy administracyjno-terytorialnej 2005 r.), jednakże nie możemy mówić o indywidualnej motywacji uczestnictwa, ponieważ władza aktywnie wykorzystywała technologie mobilizacyjne. Mobilizacyjny charakter udziału obywateli w dyskursie politycznym po-

41 Ава місяиі протестів в Україні: що далі? - загальнонащіональне опитування, Фонд „Аемократичні ініціативи імені Іьька Кучеріва”, [online] http://dif.org.ua/ua/polls/2014_polls/dva-misjaci-protestiv-v-ukraini-sho-dali_--zagalnonacionalne-opituvannja.htm. 
zwala elicie ukraińskiej na przerywanie jego przebiegu w dogodnym dla niej momencie, na stwarzanie próżni dyskursywnej poprzez aktualizację problemów nieistotnych, drugorzędnych z punktu widzenia politycznej teraźniejszości. Możliwość kształtowania dyskursu sytuacyjnego w ukraińskiej przestrzeni politycznej jest zrodzona przez istniejący i odtwarzany rozziew między strategią działań władzy i realnym kursem politycznym a oczekiwaniami obywateli; ma na nią wpływ również niezakończenie procesu instytucjonalizacji opozycji systemowej na Ukrainie, od której zależy charakter i ładunek znaczeniowy pola dyskursywnego i odpowiedniego modelu uczestnictwa politycznego.

Perspektywy rozwoju dyskursywnego modelu uczestnictwa politycznego są określane przez główne tendencje modernizacji sfery publicznej polityki na Ukrainie. Są one związane ze wzmocnieniem roli instytucji społeczeństwa obywatelskiego, wprowadzeniem mechanizmów demokratycznych do procesu kształtowania politycznego porządku dziennego, kształtowaniem się zasad odpowiedzialności obieralnych organów władzy przed wyborcami. Optymizm co do sukcesu demokratycznych procesów transformacyjnych i inicjatyw modernizacyjnych na Ukrainie związany jest z tym, że obywatele są osobiście zainteresowani użyciem w okresie międzywyborczym aktywnych form uczestnictwa politycznego, które w sposób istotny zależą od potencjału społeczeństwa obywatelskiego. Perspektywy zakończenia procesu konsolidacji demokracji na Ukrainie zależą również od tego, czy obywatele potrzebują wykorzystywać dialogową formę uczestnictwa politycznego, która przewiduje, że obywatele są równym podmiotem współdziałania zarówno w sytuacji inicjowania dialogu, jak i w trakcie jego prowadzenia, a wszyscy uczestnicy dialogu znajdują się wobec siebie w relacjach systemowych i nabierają znaczenia politycznego tylko poprzez związek i wzajemne stosunki z innymi podmiotami tego procesu.

Instytucjonalne kształtowanie się i opanowanie przez obywateli dialogowych form uczestnictwa politycznego w międzywyborczym dyskursie politycznym jest jednym z obowiązkowych parametrów zakończenia procesu konsolidacji demokracji. Perspektywy tego procesu na Ukrainie są określane przez charakter poparcia społecznego dla kontroli obywatelskiej, inicjatywy, samodzielności i krytyczności obywateli w stosunku do władzy i przez wygaszanie odnowionej przez władzę tendencji do popierania nastrojów neoetatystycznych. Rozpowszechnianiu się skłonności obywateli do wykorzystania dialogowych form politycznego uczestnictwa będzie sprzyjało publiczne zainteresowanie władzy tym procesem, stworzenie odpowiedniej bazy ustawodawczej, przekazanie obywatelom dostępu do wszystkich rodzajów informacji i wykorzystania możliwości politycznych.

Istniejący model użycia dialogowych form uczestnictwa politycznego na Ukrainie przewiduje stworzenie społecznych rad przy Radzie Ministrów Autonomicznej Republiki Krymu, wszystkich radach obwodowych, kijowskiej i sewastopolskiej miejskiej administracji państwowej i w 430 organach rejonowej (powiatowej) administracji państwowej $^{42}$. W skład rad społecznych przy rejonowych administracjach państwowych

42 Всеукраїнська благодійна організаиія „Український центр політичного менеджменту”. Звіт за результатами реалізації проекту, згідно з Угодою від 04 червня 2011 року, Київ 2011, s. 2, 14. 
weszli przedstawiciele organizacji społecznych, w skład $81,7 \%$ rad - przedstawiciele związków zawodowych, 30\% rad - przedstawiciele związków religijnych, 26\% rad reprezentanci organizacji dobroczynnych. Znacznie mniejszy udział w pracy tych rad mają przedstawiciele niepaństwowych środków masowego przekazu $(19,1 \%$ rad), organizacji pracodawców $(8,4 \% \mathrm{rad})$, związków twórczych $(7,1 \% \mathrm{rad})^{43}$.

Jest jeszcze zbyt wcześnie, by mówić o efektywności rad społecznych jako o mechanizmie realizacji przez obywateli dialogowej formy uczestnictwa politycznego. Jednak już na etapie początkowym tworzenia sieci rad społecznych obnażono szereg problemów, które pozwalają przewidywać niedostateczny poziom efektywności działań danej instytucji. W uogólnieniu propozycji członków rad społecznych przy Radzie Ministrów ARK, rad obwodowych, miejskich kijowskiej i sewastopolskiej, organów rejonowych administracji państwowych odnośnie do udoskonalenia normatywno-prawnego, zapewnienia informacyjnego i metodycznego współdziałania organów władzy wykonawczej z radami społecznymi, napotykamy propozycje, których realizacja przekształci rady społeczne z samodzielnego instytucjonalnego subiektu współdziałania w strukturę zależną od organu władzy. Mamy tu na myśli propozycje, które dotyczą wzmacniania materialno-technicznego zabezpieczenia rady (w postaci gabinetu, sprzętu komputerowego, telefonów, przyborów biurowych, transportu samochodowego do przeprowadzenia wyjazdowych rozmów spotecznych, dyskusji publicznych i konsultacji, rozdzielenia uprawnień $w$ zakresie wtaczenia spoteczności w proces podejmowania decyzji między organami wtadzy wykonawczej i radami spotecznymi w celu uniknięcia dublowania i przeniesienia wyżej rezultatów tego procesu (zgodnie z aktami normatywno-prawnymi rada społeczna formowana jest z przedstawicieli społeczności); wtaczenie przewodniczacego rady spotecznej w sktad kolegium miejscowej administracji państwowej i zaproszenie cztonków rady spotecznej do udziatu w obradach kolegium ${ }^{44}$. Przytoczone przykłady propozycji członków rad społecznych świadczą o stałym odtwarzaniu dążenia instytucji społeczeństwa obywatelskiego Ukrainy do integrowania się z systemem organów władzy, co z kolei oddala je od interesów społeczeństwa. Działalność rady społecznej rzeczywiście wymaga pewnych środków, jednak naszym zdaniem poziom i efektywność wpływu rady społecznej na działalność organów władzy określa maksymalna finansowa i organizacyjna niezależność od tych ostatnich. A jeśli instytucje społeczeństwa obywatelskiego są zainteresowane wpływaniem na władzę, to muszą one akumulować własne środki wewnętrzne - czy to intelektualne (nie prosząc o przeprowadzenie seminarium mającego na celu podniesienie własnego poziomu kultury politycznej), czy to finansowe lub organizacyjne.

Pozytywna dynamika procesu kształtowania rad społecznych przy centralnych i regionalnych organach władzy wykonawczej Ukrainy nieuchronnie wywołuje pytanie o to, na ile dane organy doradcze sprzyjają włączeniu instytucji społeczeństwa obywatelskiego do procesu podejmowania decyzji i odzwierciedlają interes społecz-

43 Інформація про утворення Громадських Рад при місцевих органах виконавчої влади, „Вісник громадських раА” 2011, nr 1, s. 17.

44 Всеукраїнська благодійна організачія..., s. 20-23. 
ny. Nie ulega wątpliwości, że w pewnych warunkach organy doradcze mogą efektywnie funkcjonować jako instrumenty społeczeństwa obywatelskiego i uczestnictwa politycznego. Jednak, charakteryzując obecny etap rozwoju dialogu między organami władzy i obywatelami, można wyróżnić tendencję do tworzenia systemu kontroli sił społecznych w celu wpływania na opinię publiczną w warunkach braku mechanizmów demokratycznych, za których pomocą odbywa się tworzenie zasobu legitymizacji dla aktualnej władzy, czyli przede wszystkim braku systemu reprezentowania interesów i niezależnych środków masowego przekazu. W tych warunkach kształtowanie organu doradczego może doprowadzić do uzyskania przezeń statusu politycznego. Zgodnie z koncepcją statusu politycznego C. Offego, stosunki korporacyjne między organami władzy i obywatelami są odzwierciedleniem systemu uczestnictwa politycznego, gdzie prawa obywateli do udziału w procesie politycznym są delegowane liderom scentralizowanych grup ${ }^{45}$. W konsekwencji system współdziałania władzy i obywateli na poziomie organów konsultacyjnych (doradczych) przy organach władzy może - w pewnych sytuacjach - uzyskiwać status polityczny, który ulega konkretyzacji przez zależność od zasobów państwa, kontrolę państwa nad reprezentacją interesów, formalną regulację stosunków wewnętrznych między członkami rady społecznej i organem władzy, prawo do udziału w podejmowaniu decyzji podczas realizacji kursu politycznego ${ }^{46}$.

Ponieważ organy doradcze powstają z inicjatywy państwa, pod wieloma względami okazują się one zależne od jego zasobów organizacyjnych i materialnych, ulegają trwałej tendencji do biurokratyzacji, co może doprowadzić do pełnej inkorporacji do struktur władzy. Aby wyodrębnić takie systemy przedstawicielstwa, które prezentują fikcyjne istnienie organizacji i marginalna role $w$ polityce publicznej, a także maskuja nierówny dostęp do procesu podejmowania decyzji ${ }^{47}$, wyróżnia się liberalny (societal corporatism pewna autonomia organu doradczego od państwa, co pozwala efektywnie bronić interesów jego członków) i państwowy (state corporatism - wynik systematycznej ingerencji władzy w proces kształtowania i funkcjonowania organu doradczego przy braku możliwości zachowywania przezeń względnej niezależności) model korporatywizmu, które rozgraniczają efektywną i fikcyjną działalność rad społecznych.

$\mathrm{Na}$ Ukrainie organy doradcze posiadają takie właściwości instytucjonalne, które w wielu wypadkach pozwalają organom władzy określać skład uczestników, procedury funkcjonowania i komponent finansowy. W warunkach słabej samodzielności finansowej organizacji społecznych możliwości organu doradczego reprezentowania interesów swoich członków w sposób istotny zmniejszają się, przekształcając go w jeszcze jeden

45 C. Offe, Attribution of Public Status to Interest Groups: Observations on the West German Case, [w:] Organizing Interests in Western Europe. Pluralism, Corporatism, and the Transformation of Politics, red. S. Berger, Cambridge-New York 1981, s. 139, Cambridge Studies in Modern Political Economies.

46 F. Wilson, Review: Interest Groups and Politics in Western Europe. The Neo-Corporatist Approach, „Comparative Politics” 1983, Vol. 16, nr 1, s. 106, [online] http://dx.doi.org/10.2307/421599.

47 Ph. Schmitter, Still the Century of Corporatism?, [w:] The New Corporatism. Social-Political Structures in the Iberian World, red. R. Pike, T. Stritch, Notre Dame 1974, s. 124, International Studies of the Committee on International Relations, University of Notre Dame. 
kanał transmisji polityki państwowej. Faktycznie organy doradcze wykonują funkcję legitymizacyjną, czemu sprzyjają warunki kształtowania państwowego modelu korporatywizmu. Dlatego też wyniki działalności nowych instytucji, które powinny były sprzyjać rozwojowi dialogu społecznego i społeczeństwa obywatelskiego w ogóle, nie pozwalają mówić o znacznych sukcesach we wdrażaniu idei modernizacji politycznej, ponieważ wykonują one ukryte funkcje legitymizacyjne i przeważnie nie odpowiadają potrzebom reprezentacji interesów społecznych. W przypadku gdy systemy przedstawicielstwa będą niezależne od państwowego finansowania i będą tworzone z inicjatywy instytucji regionalnych społeczeństwa obywatelskiego, będą one zdolne do efektywnego wyrażania interesów społecznych, co będzie świadczyło o pewnym stopniu politycznej modernizacji procesu zarządzania.

$\mathrm{Na}$ Ukrainie powstała paradoksalna sytuacja funkcjonowania społeczności demokratycznej w środowisku politycznym o niskim stopniu konkurencyjności. Jednocześnie, wraz z wzrostem procentu obywateli aktywnych politycznie, zorientowanych na racjonalne, do pewnego stopnia autonomiczne uczestnictwo polityczne, będzie spadała liczba obywateli gotowych przyjmować dość pasywną rolę przeznaczoną dla nich w modelu stosunków „patron-klient” albo pogodzić się z ograniczeniami ich prostego włączenia, które chcieliby im narzucić liderzy partyjni. Podobnie jak w krajach stabilnej demokracji preferowane będą inne kanały politycznej aktywności, w tym również typu pozapartyjnego, które zaspokajały będą zapotrzebowanie obywateli na bezpośrednie uczestnictwo polityczne.

Na przeszkodzie kształtowaniu efektywnych i skutecznych wzajemnych stosunków między władzą i społeczeństwem stoi stabilny brak konsensusu co do zasad funkcjonowania systemu politycznego Ukrainy, przede wszystkim między instytucjonalnymi podmiotami polityki. Główne przyczyny tego leżą w braku odpowiednich tradycji w historii politycznej Ukrainy i nie zawsze adekwatnym rozumieniu treści wartości demokratycznych, które tak czy inaczej nadal są podporządkowywane przez wszystkie segmenty elity politycznej problemowi sprawiedliwości społecznej, podczas gdy kompromis polityczno-prawny pomiędzy głównymi podmiotami procesu politycznego powinien kształtować się w oparciu o poziom konstytucyjny i bazowy stosunków politycznych. Podstawą pierwszego poziomu jest uznanie państwa za najwyższą instancję oraz uznanie formalnych norm i wartości deklarowanych przez konstytucję przez wszystkich aktorów sceny politycznej. Konsensus konstytucyjny jest ograniczony do listy demokratycznych reguł gry politycznej i nie pretenduje do uzgodnienia głównych zagadnień ekonomicznych i politycznych, można go określić jako podstawę do podjęcia pewnych decyzji co do dróg dalszego rozwoju Ukrainy, pod warunkiem zapewnienia możliwości dużej zmienności decyzji politycznych. Dopiero po osiągnięciu konsensusu konstytucyjnego można mówić o obniżeniu wpływu czynników, które doprowadzają do polityczno-kulturalnej fragmentacji przestrzeni politycznej, i o konieczności skupienia wysiłków instytucjonalnych podmiotów procesu politycznego na osiągnięciu bazowego konsensusu. Jego podstawą na Ukrainie mogą stać się: model niekorporacyjny uzgodnienia interesów politycznych, przyswojenie przez obywateli dialogowych form uczestnictwa politycznego i integracja kraju z zachodnioeuropejską wspólnotą narodów. 
Kształtowaniu konstruktywnych wzajemnych stosunków w systemie wtadza-spoteczeństwo nie sprzyja również stabilna asymetria pionowych związków między strukturami władzy i obywatelami. Główną przyczyną asymetrii jest, naszym zdaniem, niedokończenie procesu instytucjonalizacji systemu reprezentacji interesów obywateli, bark ustalonych tradycji uczestnictwa politycznego i stereotypowy pogląd przedstawicieli struktur władzy, że większa jest efektywność monologu władzy aniżeli nawiązanie dialogu w systemie $w$ tadza-obywatele. Ważne jest, by zarówno władza, jak i społeczeństwo uświadamiały sobie konieczność kształtowania skutecznych instytucji społeczeństwa obywatelskiego jako zbioru niezależnych od państwa aktorów i kanałów komunikacji, odrębnego od przestrzeni politycznej, która jest sferą funkcjonowania partii politycznych, organizacji, polityki publicznej. Jednocześnie nie ma wyraźnego podziału między społeczeństwem obywatelskim i sferą polityczną, ponieważ społeczeństwo obywatelskie zdolne jest do otwierania drogi do polityki dla nowych podmiotów, które włączają do dyskursu politycznego nowe problemy i wartości.

\section{BIBLIOGRAFIA}

Offe C., Attribution of Public Status to Interest Groups: Observations on the West German Case, [w:] Organizing Interests in Western Europe. Pluralism, Corporatism, and the Transformation of Politics, red. S. Berger, Cambridge-New York 1981, Cambridge Studies in Modern Political Economies.

Schmitter Ph., Still the Century of Corporatism?, [w:] The New Corporatism. Social-Political

Structures in the Iberian World, red. R. Pike, T. Stritch, Notre Dame 1974, International

Studies of the Committee on International Relations, University of Notre Dame.

Wilson F., Review: Interest Groups and Politics in Western Europe. The Neo-Corporatist Approach, „Comparative Politics” 1983, Vol. 16, nr 1, [online] http://dx.doi.org/10.2307/421599.

Ахременко А., Мемешкина Е., Голосование „Против всех” как форма политического протеста: проблемь изучения, „Политическая наука” 2002, nr 1.

Байхемьт Т., Павленко Р., Президентські вибори $і$ конституиійна реформа, [w:] Президентські вибори та Помаранчева революиіл. Вплив на трансформаційні прочеси в Україні, red. Г. Курт, I. Кемпе, В.I. Андрійко, Київ 2005.

Балакірєва О., Міщенко М., Яременко О.,Аинаміка тачинники формуванняелекторальних орієнтаиійгромадян України підчас виборчої кампаніїі, „Політичний портрет України” 2000, nr 22.

Вибір України-99. Що далі. Збірник статей і довідкових матеріалів, red. Я. Хобота і іn., Київ 1999.

Вибори Президента України 1999. Інформаиійно-аналітичне видання, red. М. Рябець, М. Ставнійчук, Київ 2000.

Вибори Президента України 2004 року. Електоральна статистика. Інформаиійно-аналітичне видання, red. Я. Аавидович, Київ 2005.

Вибори Президента України. Повторне голосування 7 лютого 2010 року. Протокол 
Центральної виборчої комісії про результати повторного голосування з виборів Президента України, Центральна виборча комісія, [online] http://www.cvk.gov.ua/ visnyk/pdf/2010_1/visnik_st_4.pdf.

Вибори-2014: сподівання громадян, рейтинги кандидатів, мотивація вибору, ФонА „Аемократичні ініціативи імені Іиька Кучеріва”, [online] http://dif.org.ua/ua/publications/press-relizy/jlvklvlvllvm.htm.

Від Майдану-табору до Майдану-січі: що змінилося?, ФонА „Аемократичні ініціативи імені Іиька Кучеріва”, [online] http://dif.org.ua/ua/polls/2014_polls/vid-maidanu-taboru-do-maidan.htm.

Всеукраїнська благодійна організація „Украӥнський центр політичного менеджменту”. Звіт за результатами реалізачї проекту, згідно з Угодою від 04 червня 2011 року, Київ 2011.

Головаха Е.И., Политическая информированность, компетентность и активность населения, [w:] tenże, Политическал культура населения Украиньь. Результатьь сочиологических исследований, Київ 1993.

Ава місяці протестів в Україні: що далі? - загальнонаціональне опитування, ФонА „Аемократичні ініціативи імені Іцька Кучеріва”, [online] http://dif.org.ua/ua/ polls/2014_polls/dva-misjaci-protestiv-v-ukraini-sho-dali_--zagalnonacionalne-opituvannja.htm.

Аумка киян та експертів про подї в Україні, „Політичний календар. Інформаційно-анамітичний огмяд” 2001, nr 1.

Експертне опитування „Вибори-2014: сподіване і несподіване”, ФонА „Аемократичні ініціативи імені Іиька Кучеріва”, [online] http://dif.org.ua/ua/publications/press-relizy/ nktgnkejnrkhjnkejrhk.htm.

ЖАанов I., Вибори-2002: соло для адміністративного ресурсу?, „Азеркало тижня” 2001, 22 XII.

Інформація про утворення Громадських Рад при місиевих органах виконавчої влади, „Вісник громадських раА” 2011, nr 1.

Кремень В.Г. і іn., Соціально-політична ситуачія в Україні. Поступ п’яmи років. Монографія, Київ 1996.

Аипсет С., Структуры размежеваний, партийнье системь и предпочтения избирателей, [w:] С. Аипсет, С. Роккан, Партии и вььборьь. Хрестоматия, red. Н. Анохина, Е. Мемешкина, сz. 1, Москва 2004.

Майдан-2013: хmо стойть, чому $i$ за щзо?, ФонА „Аемократичні ініціативи імені Іیька Кучеріва”, [online] http://dif.org.ua/ua/polls/2013-year/mogjorjghoeoj.htm.

Майдан-мітинг і Майдан-табір: схоже і відмінне, ФонА „Аемократичні ініціативи імені Іцька Кучеріва”, [online] http://dif.org.ua/ua/polls/2013-year/vjweojgvowerjoujgo.htm.

Офічійні результати виборів Президента Украӥни 1 грудня 1991 р., „Урядовий кур'єр” 1991, nr 38-39.

Паніна Н., Украйнське суспільство 1994-2005. Соціологічний моніторинг, Київ 2005.

Позачергові вибори Президента Украӥни 25 травня 2014 року. Підсумки голосування в межах регіонів України, [online] http://www.cvk.gov.ua/vp2014/wp001.html.

Позачергові вибори Президента України 25 травня 2014 року. Підтримка лідерів по регіонах, [online] http://www.cvk.gov.ua/vp2014/wp001.html. 
Позачергові вибори Президента України 25 травня 2014 року. Примірник Nr 1. Протокол Центральної Виборчої Комісії „Прорезультати Виборів Президента України”, Центральна виборча комісія, [online] http://www.cvk.gov.ua/info/protokol_cvk_25052014.pdf.

Політична криза в Украӥні: еволючія та головні уроки, „Політичний календар. Інформаційно-аналітичний огмяА” 2001, nr 6.

Політичні партії в Україні напередодні парламентських виборів: стан $і$ тенденцї (Аналітична доповідъ УЦЕПА), „Націонацьна безпека і оборона” 2001, nr 12.

Про Президентство, [w:] Матеріали I-V зиздів Сочіалістичної партї України, red. О. Мороз, t. 1: 1991-1994, Київ 1997.

Проблеми проведення президентських виборів у Аонецькій і Ауганській областях, ФонА „Аемократичні ініціативи імені Ілька Кучеріва”, 25 V 2014, [online] http://dif.org.ua/ ua/polls/2014_polls/sdmnvkasjovjojvoajf.htm.

Програма Freedom House „Участь громадян у вибориих процесах в Україн”. Ставлення громадян України до інституту виборів та їх наміри участі у виборах, [online] http:// www.freedomhouse.org.ua/print/publications/investigations/.

Ротар Н., Етнонаціональні чинники політичної участі громадян України, „Наукові записки. Курасівські читання-2005. Політологія та етнологія” 2006, nr 30, ks. 1.

Ротар Н., Політична участь громадян Украйни у системних трансформачіях перехідного періоду, Чернівці 2007.

Уилсон Э., Новал виртуальная политика Украиньь, „Конституционное право. Восточноевропейское обозрение" 2001, nr 3.

Україна, 2004 рік: перебіг президентської виборчої кампанї очима громадян, „Національна безпека і оборона” 2004, nr 10.

Шаран П., Сравнительная политология, сz. 2, Москва 1992.

Ttumaczenie Przemystaw Tomanek

Prof. dr hab. Natalia ROTAR - doktor habilitowany nauk politycznych, profesor Katedry Politologii i Zarządzania Państwem Narodowego Uniwersytetu Czerniowieckiego im. Jurija Fedkowycza. 